Review Article

\title{
MAJOR AGRONOMICAL RESEARCH WORKS AT THE INSTITUTE OF AGRICULTURE AND ANIMAL SCIENCES, RAMPUR, CHITWAN, NEPAL: A REVIEW
}

\author{
L. P. Amgain ${ }^{1}$ and J. Timsina ${ }^{2}$ \\ ${ }^{1}$ Institute of Agriculture and Animal Sciences, Rampur, Chitwan, Nepal \\ ${ }^{2}$ CSIRO Land and Water, Griffith Laboratory, Griffith, NSW 2680, Australia
}

\begin{abstract}
The Institute of Agriculture and Animal Sciences (IAAS) under Tribhuvan University (TU) has been conducting various disciplinary and system research works, and publishing the findings through the IAAS Journal, IAAS Research Reports, and Nepalese Journal of Agriculture for over 25 years. A literature review was done to appraise the agronomical research works on major field crops and cropping systems at IAAS, Rampur, Chitwan, Nepal. The objectives were to summarize the results of various agronomic research works at the institute to determine the extent and causes of yield gaps of major crops, and to identify the future research priorities. The review revealed that the on-station research at IAAS in the past were conducted on 14 crops, on maize-and wheat-based systems and on 5 major themes. The main themes of research in most crops were varietal evaluation and breeding, crop management, soil management, weed management and pest management though in some crops research was conducted on other themes too. A total of 81 studies were conducted on various crops, of which 48 were on cereals, 14 on legumes, 10 on oilseed crops, and 6 on potato. There were 2 studies on wheat-based and a single study on maize-based systems. Average potential yields of rice, maize and wheat were 5.5, 4.4 and 5.0 t/ ha, while research station yields and farmers' field yields of these crops were 3.4, 3.3 and $3.5 \mathrm{t} / \mathrm{ha}$ and 2.7, 1.8 and $1.9 \mathrm{t} / \mathrm{ha}$, respectively, in Chitwan. The yield gaps between the potential and farmers' field for those crops were $2.76,2.58$ and $3.15 \mathrm{t} / \mathrm{ha}$, while those between potential and research station yields were 2.1, 1.1 and $1.53 \mathrm{t} / \mathrm{ha}$, respectively. The gaps between research station and farmers' field yields were much smaller in rice $(0.66 \mathrm{t} / \mathrm{ha})$ than in maize $(1.48 \mathrm{t} / \mathrm{ha})$ and wheat $(1.62 \mathrm{t} / \mathrm{ha})$. The results suggest that there is a great scope to raise yields of all cereals in farmers' fields, more so for wheat and maize than for rice. Improved agronomical research on rice varieties and crop and soil management required to reduce the yield gap for rice, while adoption of recommended technologies by farmers would help reduce yield gap in wheat. For soybean, lentil, and potato, the gap between potential and farmers' yields is much larger than the other yield gaps suggesting large scope for increase in yields in farmers' fields through both improved management and improved varieties. Innovative and new researches on eco-region suited variety identification, improved crop and soil management, improved water and $\mathrm{N}$ management and on agro-meteorology and crop modeling are suggested as priorities for future research to uplift the productivity and reduce yield gaps of major crops in Chitwan district of Nepal.
\end{abstract}

Key words: Field crops, on-station research, on-farm research, crop productivity, yield gap analysis

\section{INTRODUCTION}

The Institute of Agriculture and Animal Sciences (IAAS) under Tribhuvan University (TU), situated in the central Terai region of Nepal $\left(27^{0} 37^{\prime} \mathrm{N} ; 84^{\circ} 25^{\prime} \mathrm{E}\right.$ and 256 masl.) has humid sub-tropical climate with a warm and monsoon summer during June-September and cold winter during November-February (Sharma et al., 1984). The area is dominated by light textured sandy loam soil with acidic reaction ( $\mathrm{pH} 5.5$ to 6.5) and deficient soil available N (Khakural et al., 1984). The institute has a long history of integrating research works with teaching and extension activities. This integration is imperative and relevant for the needs of the country, however, it does not receive any core funds from national government to undertake its research programs, but the institute itself provides its faculties with small grants from its own internally generated resources. These grants have given continuity to the research program of the institute. In addition, its faculties have been receiving substantial competitive research grants from national and international donor organizations. Thus, the institute has been maintaining the spirit of research in agriculture and animal sciences to solve the agricultural problems of the country. The IAAS, for this reason, has established a Directorate of Research and Publication (DOR) to 
institutionalize and strengthen its research program. The DOR, along with information generated from externally and internally funded projects, also publishes scientific information through the IAAS Journal and IAAS Research Reports. Since the institute is located in the central Terai region, it has focused its research activities to suit the Terai and inner Terai regions, especially to Chitwan and adjoining districts. By launching the Master Programs in 13 Departments and Doctoral Programs in 3 Departments, the IAAS has piled up the several theses and resulting papers (IAAS Bulletin, 2003). The availability of about 50 hectares of cultivable land under Agronomy Farm provides sufficient land to conduct on-station agronomical research at IAAS, but many research activities are also conducted in the farmers' field (on-farm). Some research works of IAAS faculties have also published in the Nepalese Journal of Science and Technology, Nepalese Journal of Agriculture, and some international journals and newsletters. The National Maize Research Program (NMRP) and National Grain Legumes Research Program (NGLRP) under Nepal Agriculture Research Council (NARC) are located across the road outside the main campus of IAAS and they have also been conducting the research suited to Terai and inner Terai regions.

Rice, maize, wheat and potato are the major crops prioritized by the Agricultural Perspective Plan of Nepal (APP, 1995). Nevertheless, other crops, such as finger millet, groundnut, soybean, mungbean and cowpea are also grown during the monsoon/spring season and rapeseed and mustard, buckwheat, lentil and chickpea during the winter season in Terai and Inner-terai regions. To overcome the problem of food insecurity and poverty, the agriculture research institutions of Nepal have provided several need-based output-oriented research findings but they all are not practiced in the farmers' fields (Joshy and Rajbhandadri, 2001). To date, the several agronomical investigations conducted in Nepal and documented in the literature are concentrated on variety selection and identification, cultural and management practices, fertility maintenance, weed control, etc. Though the large amounts of research efforts are going on and various papers are published in national proceedings, journals, workshop papers and booklets, their systematic documentation in the form of a consolidated paper is lacking. Hence, an attempt was made to compile and review the agronomic research works conducted to date at IAAS, Chitwan, Nepal. The main objective of this paper was to review and summarize the current activities and achievements related to agronomical research at IAAS, Rampur, to determine the yield gaps, and to identify future research priorities based on the published and unpublished data.

\section{THE APPROACH AND METHODOLOGY}

More than 81 agronomical research results published in the IAAS Journal (1977-2002), IAAS Research Reports (1985-2001) and Nepalese Journal of Agriculture (1985) were compiled and reviewed. There were large numbers of agronomical studies conducted in farmers' fields through farming system research and extension projects (Timsina, 2001). Only those researches conducted by the past and present faculties of IAAS were included in the review. However, it also included the work of researchers of NMRP and NGLRP who collaborated with the researchers of IAAS on various researches. Findings under various management themes/issues on various crops are summarized in tables and briefed in texts. In addition, the gaps between the potential and the experimental station yields, between experimental station and farmers' field yields and between potential and farmers' field yields were determined and causes of yield gaps were identified for major crops. The causes of low productivity of major field crops are presented and future research priorities are also provided.

\section{RESULTS AND DISCUSSION}

\section{Major research accomplishments}

Over the past 25 to 30 years, the on-station and on-farm research at IAAS was conducted on 14 crops, on maize- and wheat- based systems, and 5 major themes (Table 1). Among them, rice, maize, wheat, soybean, rapeseed and mustard, and potato were the main crops, in which most research works were concentrated. The main themes of research works were: varietal evaluation and breeding, crop management (plant spacing and population, seed rate and sowing date, system for rice intensification (SRI), seed priming, seed inoculation, water management, etc.), soil management (land preparation methods, tillage options, compost, residues and green manuring, and inorganic fertilizer management), weed management (weed population, species, and control methods), and pest management (insect pest and disease management). Table 1 further shows that rice research was carried out on all themes but the focus was on weed management. In wheat, though there was substantial 
research works carried out on all themes, the main focus was on varietal evaluation and breeding, and on soil management. In maize, the focus was on soil management, while in soybean it was on varietal development. In rapeseed, mustard and potato, the research works were carried out on all themes, except varietal management. These research activities are briefly discussed and summarized in Tables 2 to 5 .

Table 1. Summary of on-station and on-farm research on major agronomic crops at IAAS, Rampur, Chitwan

\begin{tabular}{|c|c|c|c|c|c|c|}
\hline \multirow[t]{2}{*}{ Crop } & \multicolumn{6}{|c|}{ Major issues/themes } \\
\hline & $\begin{array}{l}\text { arietal performance } \\
\text { and breeding }\end{array}$ & $\begin{array}{c}\text { Crop } \\
\text { management }\end{array}$ & $\begin{array}{c}\text { Soil } \\
\text { management }\end{array}$ & $\begin{array}{c}\text { Weed } \\
\text { management }\end{array}$ & $\begin{array}{c}\text { Pest } \\
\text { management }\end{array}$ & Total \\
\hline Cereals & & & & & & 48 \\
\hline Rice & 2 & 1 & 3 & 6 & 2 & 14 \\
\hline Maize & - & 2 & 4 & 1 & 1 & 8 \\
\hline Wheat & 11 & 2 & 6 & 2 & 2 & 23 \\
\hline Finger millet & - & 1 & - & - & - & 1 \\
\hline Buckwheat & 2 & - & - & - & - & 2 \\
\hline Legumes & & & & & & 14 \\
\hline Soybean & 5 & 2 & - & - & - & 7 \\
\hline Mungbean & - & 2 & 2 & - & - & 4 \\
\hline Cowpea & - & 2 & - & - & - & 2 \\
\hline Lentil and Chickpea & - & 1 & - & - & - & 1 \\
\hline Oilseed crops & & & & & & 10 \\
\hline Rape seed and mustard & $\mathrm{rd}$ & 3 & 2 & 1 & 1 & 7 \\
\hline Ground nut & 2 & - & - & - & - & 2 \\
\hline Sunflower & - & 1 & - & - & - & 1 \\
\hline Potato & - & 1 & 3 & 1 & 1 & 6 \\
\hline Total & 22 & 18 & 20 & 11 & 7 & 78 \\
\hline Cropping system & & & & & & 3 \\
\hline Maize-based & & & Maize - Soybean - & & & 1 \\
\hline Wheat-based & & Wheat & entil 1, Winter Crc & ed -1 & & 2 \\
\hline
\end{tabular}

Source: Modified from Amgain and Timsina (2004); The figures denote the numbers of research papers published in IAAS Journal, IAAS Research Reports and Nepalese Journal of Agriculture)

\section{Monsoon/spring season crops}

Rice (Oryza sativa L.)

\section{Varietal evaluation and pest management}

Varietal evaluation on rice was mostly concentrated on screening rice varieties for blast and blight resistances. The incidence of blast was less in rice cultivars Makawanpur-1 and Sabitri than in Masuli, Chaite-4, Radha-17 and Sarju-49 at Rampur and similar sub-tropical humid zones (Shrestha and Mishra, 1994; Shrestha and Bhardwaj, 1985). Rice cultivar, IR-10781-143, was fully to moderately resistant to blast throughout crop cycle, while IR46 and IR-8423 were susceptible at early and late stages, respectively. BG-400-1 was susceptible to leaf blight at early crop stage, while NR-6-7-83 was susceptible at late stage (Karki, 1991). Despite high incidence of blast at Rampur and similar sub-tropical humid zones, Masuli variety performed better and was found to be very common among Nepalese farmers (Dahal et al., 1995).

\section{Crop management}

A crop management study at IAAS, Rampur was conducted following the principle of rice intensification system (SRI) in which two weeks old single seedlings were transplanted at $40 \mathrm{~cm}$ x $40 \mathrm{~cm}$ spacing. Such method of planting produced significantly higher yield through better tillering and better root growth, and through synergistic effect of crop-soil environment. The highest yield was for Radha-4 (3.85 t/ha) followed by Sabitri (3.54 t/ha) and Makawanpur-1 (3.43 t/ha). On the same experiment, basamid treated solarized plot produced higher rice yield (3.66 t/ha) over vitavex (3.43 t/ha) (Amgain and Dahal, 2002). 


\section{Soil management}

Soil management studies in rice were conducted by comparing green manuring using various legume crops with N, P, and K fertilizers. Dahal et al. (1993) reported that Crotolaria spp as green manure without N, $\mathrm{P}_{2} \mathrm{O}_{5}, \mathrm{~K}_{2} \mathrm{O}$ yielded higher rice yield (2.43 t/ ha) followed by $90: 40: 40 \mathrm{~kg} \mathrm{~N}, \mathrm{P}_{2} \mathrm{O}_{5}, \mathrm{~K}_{2} \mathrm{O} /$ ha without Crotolaria spp $(1.80 \mathrm{t} / \mathrm{ha})$. The organic residues and mulching materials $(3 \mathrm{t} / \mathrm{ha}$ wheat straw) applied together with $\mathrm{N}$ fertilizers (100 kg/ha) in Masuli increased its growth, yield attributes and yield (Adhikari et al., 2002). Green manuring with Sesbania aculeata L. supplied about $50 \mathrm{~kg}$ available N/ha to the subsequent paddy field (Pandey, 1983). Green leaf manuring with Asuro (Adhatoda vasica L.) significantly produced 35-39\% higher rice yield over the farmers' practice (compost @10 and 25 t/ha) and 19-49\% over the chemical fertilizer (60:30:30 kg N, $\mathrm{P}_{2} \mathrm{O}_{5}$, $\mathrm{K}_{2} \mathrm{O} / \mathrm{ha}$ ). Titepati (Artemisia vulgaris), Khirra (Sapium insigne) and Dhaincha (Sesbania cannabina L.) are also potential $\mathrm{N}$ enriching crops, but research is necessary to verify their potentiality.

\section{Weed management}

Weed management studies in rice was mainly focused on the identification of different species and their control practices at IAAS, Rampur conditions. The weed survey results revealed that there were about 63 weed species, including both the facultative and obligate weeds at Rampur and its surroundings. Of these, 15 weeds belonged to the Poaceae and Cyperaceae families and rest to others. Among the facultative weeds, three weeds, Ageratum conyzoides L., Sachharum spontanneum L.and Crysopogon acyculatus (Retz.) Trin. were the most problematic ones (Gupta et al., 1977). Study of weed flora of 148 species belonging to 106 genera and 45 families indicated that Poaceae (25 spp.), Asteraceae (17 spp.), Cyperaceae (16 spp.), and Fabaceae (13 spp.) were the main families accounting for 60\% of the total weed species (Dangol et al., 1993; Dangol and Bhattarai, 1993; Dangol et al., 1986; Dangol, 1998-99) and that rice crops were infested by most of the weeds belonging to those families. Of all, Ageratum conyzoides L., A. houstonianum Mill., Cynodon dactylon L. and Digitaria adscendens (HBK) Henr., were the major weeds at Rampur. The major weeds of rice were Caesulea axillaris Roxb., Cyperus difformis L., Fimbristylisschoenoides (Retz) Vahl, F. miliaceae (L.) Vahl, Ludwigia perennis L., Monochoria vaginali (N. Burm.) Presl., Echinochloa colona (L.) Link, Ischaemum rugosum Salisb., Rotala indica (Willd.) Koehne, and Utricularia aruea Lour. Butachlor@1 kg a.i./ha and Fluchloralin@0.75 kg a.i./ha were effective herbicides to control weeds of families Poaceae, Cyperaceae and Asteraceae. Two hand weeding at 21 and 42 days after transplanting also showed comparable results to Butachlor and Fluchloralin (Chaudhary et al., 1993).

Table 2. Major technologies tested in rice research at IAAS, Rampur, Chitwan

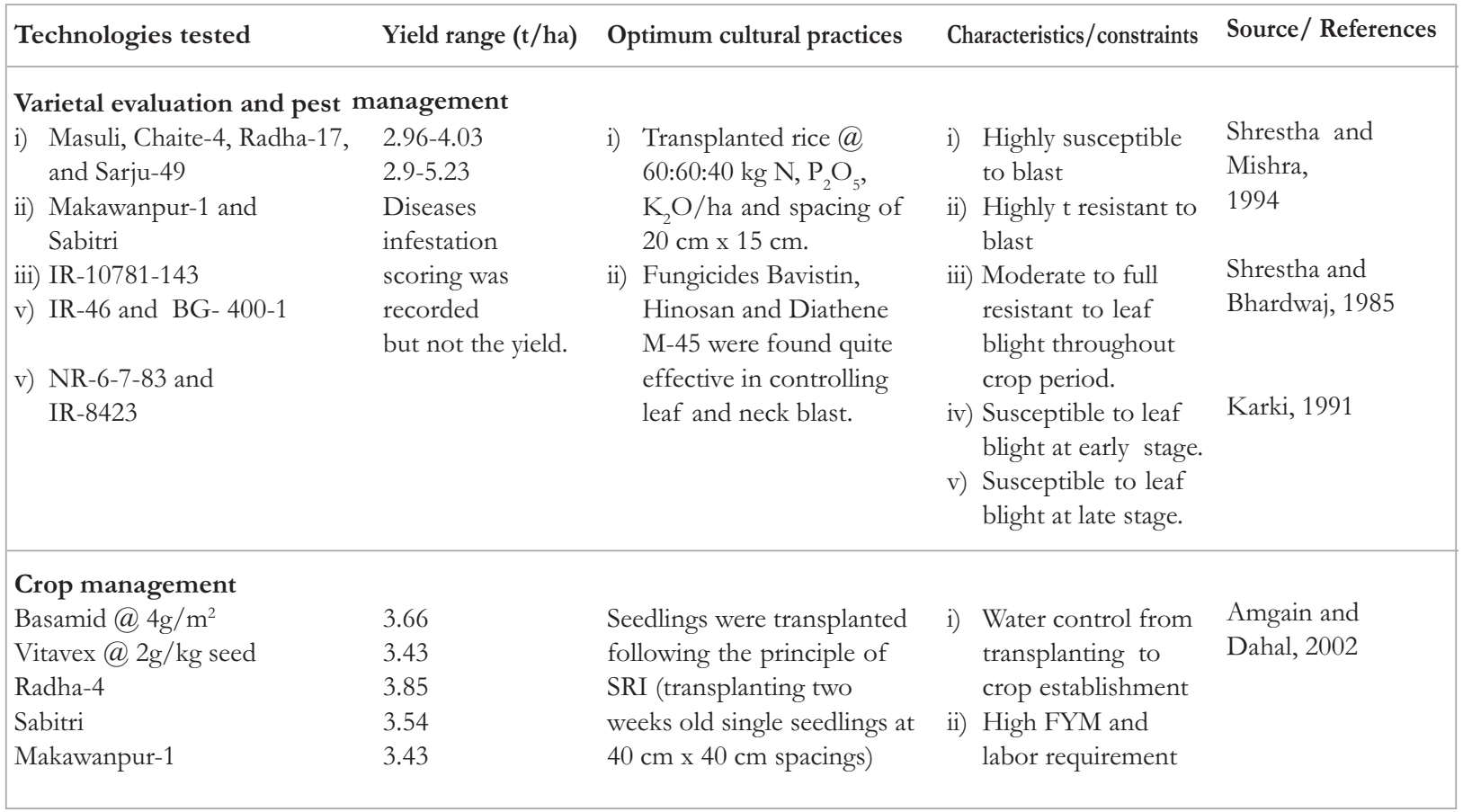


Table 1 Cont......

\begin{tabular}{|c|c|c|c|c|}
\hline Soil management & Yield range (t/ha) & Optimum cultural practices & Characteristics/constraints & Source/ References \\
\hline $\begin{array}{l}\text { i) Green manuring with } \\
\text { Crotolaria } \\
\text { ii) } 90: 40: 40 \mathrm{~kg} \mathrm{~N}, \mathrm{P}_{2} \mathrm{O}_{5} \text {, } \\
\mathrm{K}_{2} \mathrm{O} / \mathrm{ha} \\
\text { iii) Green manuring with } \\
\text { Sesbania } \\
\text { iv) Green manuring with Asuro } \\
\text { v) } 10 \text { t compost/ha } \\
\text { vi) } 60: 30: 30 \mathrm{~kg} \mathrm{~N}, \mathrm{P}_{2} \mathrm{O}_{5} \text {, } \\
\mathrm{K}_{2} \mathrm{O} / \mathrm{ha} \\
\text { vii) Control }\end{array}$ & $\begin{array}{l}4.74 \\
2.75 \\
2.95 \\
1.60\end{array}$ & $\begin{array}{l}\text { i) Sesbania can substitute } \\
50 \% \text { cost of } \mathrm{N} \text { fertilizer } \\
\text { ii) Green manuring with } \\
\text { Asuro recorded } 35-39 \% \\
\text { and } 19-49 \% \text { higher yield } \\
\text { over } 10 \mathrm{t} / \mathrm{ha} \text { compost } \\
\text { and } 60: 30: 30 \mathrm{~kg} \mathrm{~N}, \\
\mathrm{P}_{2} \mathrm{O}_{5}, \mathrm{~K}_{2} \mathrm{O} / \mathrm{ha} \text {, } \\
\text { respectively }\end{array}$ & $\begin{array}{l}\text { Non-availability of } \\
\text { green manures and } \\
\text { requirement for high } \\
\text { amounts of FYM. }\end{array}$ & $\begin{array}{l}\text { Dahal et al., 1993; } \\
\text { Pandey, } 1983\end{array}$ \\
\hline $\begin{array}{l}\text { Weed management } \\
\text { Butachlor@1 kg a.i. /ha } \\
\text { Fluchloralin@0.75 kg a.i. /ha } \\
\text { Benthiocarb@1 kg ai./ha } \\
\text { 2,4-D@1 kg a.i.ha } \\
2 \text { hand weedings } \\
1 \text { hand weeding } \\
\text { Control }\end{array}$ & $\begin{array}{l}4.5 \\
4.6 \\
3.9 \\
3.7 \\
4.2 \\
3.4 \\
2.9\end{array}$ & $\begin{array}{l}\text { Two hand weedings at } 21 \\
\text { and } 42 \text { days after transplant- } \\
\text { ing produced equal yield as } \\
\text { obtained with either } \\
\text { Butachlor or Fluchloralin, } \\
\text { and higher than with } \\
\text { Benthiocarb or 2,4-D. }\end{array}$ & $\begin{array}{l}\text { High incidence of } \\
\text { weeds of families } \\
\text { Poaceae, Cyperaceae } \\
\text { and Asteraceae, and an } \\
\text { insectivorous weed } \\
\text { Utricularia aruea Lour. }\end{array}$ & $\begin{array}{l}\text { Gupta et al., 1977; } \\
\text { Chaudhary et al., } \\
\text { 1993; } \\
\text { Dangol et al, } 1993\end{array}$ \\
\hline
\end{tabular}

\section{Maize (Zea mays L.)}

\section{Crop management}

Crop management studies on maize were concentrated on plant population, defoliation, and seed priming. The effects of thinning times on maize revealed the non-significant effect on grain yield. Random tasseling before $75 \%$ pollen shed at optimum population (66000 - 70000 plants $/$ ha) resulted in higher yield as compared to control and other foliage removal practices. Decapitation above the ear stalk and removal of lower leaves reduced grain yield but production of fresh green fodder was the highest. The higher planting densities after thinning to low and constant plant stand gave higher fresh green fodder (Adhikari, 1990). Koirala and Alipit (1986) found that seed priming by wetting and drying (1-4 cycles) before sowing maize improved the seed germination and seedling vigor over the control.

Table 3. Major technologies tested in various summer crops-based research at IAAS, Rampur, Chitwan

\begin{tabular}{|c|c|c|c|c|c|}
\hline Crops & Technologies tested & $\begin{array}{l}\text { Yield range } \\
\text { (t/ha) }\end{array}$ & Optimum cultural practices & Characteristics/constraints & Source/ References \\
\hline Maize & $\begin{array}{l}\text { Soil Management } \\
\text { Conventional tillage } \\
+2 \text { weedings } \\
\text { Minimum tillage } \\
\text { with one ploughing } \\
\text { Minimum tillage } \\
\text { No tillage }\end{array}$ & $\begin{array}{l}3.32 \\
2.56 \\
0.57 \\
0.18\end{array}$ & $\begin{array}{l}\text { i) Summer maize } \\
\text { sown at } 75 \mathrm{~cm} \times 25 \mathrm{~cm} \\
\text { spacings, } \\
\text { ii) } 60: 40: 30 \mathrm{~kg} \\
\mathrm{~N}, \mathrm{P}_{2} \mathrm{O}_{5}, \mathrm{~K}_{2} \mathrm{O} / \mathrm{ha} \text {, } \\
\text { Atrazine @ } 1 \mathrm{~kg} \text { a.i. } / \mathrm{ha} \\
\text { iii) Earthing up at } 28 \text { days of } \\
\text { sowing. }\end{array}$ & $\begin{array}{l}\text { i) The soils of IAAS were } \\
\text { deficient in N, Zn, Fe, B, } \\
\text { and Mo } \\
\text { ii) The rainfed maize yield } \\
\text { was dependent on the } \\
\text { amount and frequency of } \\
\text { irrigation }\end{array}$ & $\begin{array}{l}\text { Sharma et al., 1985; } \\
\text { Khadka and Sah, 1993; } \\
\text { Khatri-Chhetri and } \\
\text { Schulte, 1985a, b }\end{array}$ \\
\hline Finger millet & $\begin{array}{l}\text { Crop and nutrient management } \\
\text { Plant population x variety } \\
\text { Dalle-1with } 750 \\
\text { thousands plant/ha } \\
\text { Local with } 1000 \\
\text { thousands plant/ha } \\
\text { Nutrient levels } \\
40: 20: 20 \mathrm{~kg} \\
\mathrm{~N}, \mathrm{P}_{2} \mathrm{O}_{5}, \mathrm{~K} 2 \mathrm{O} / \mathrm{ha} \\
60: 30: 20 \mathrm{~kg} \\
\mathrm{~N}, \mathrm{P}_{2} \mathrm{O}_{5}, \mathrm{~K} 2 \mathrm{O} / \mathrm{ha} \\
60: 40: 30 \mathrm{~kg} \\
\mathrm{~N}, \mathrm{P}_{2} \mathrm{O}_{5}, \mathrm{~K} 2 \mathrm{O} / \mathrm{ha}\end{array}$ & $\begin{array}{l}0.87 \\
1.63 \\
2.31 \\
2.70 \\
2.23\end{array}$ & $\begin{array}{l}\text { i) } \mathrm{N}_{2} \mathrm{P}_{2} \mathrm{O}_{5}, \mathrm{~K}_{2} \mathrm{O} @ \\
40: 20: 20 \mathrm{~kg} / \mathrm{ha} \\
\text { ii) Plant population of } 250 \\
\text { thousands/ha for HYVs and } \\
\text { higher population for local } \\
\text { cultivar }\end{array}$ & $\begin{array}{l}\text { i) Weeds seem to be the } \\
\text { major problem. } \\
\text { ii) Some cultivars showed } \\
\text { higher yields with low } \\
\text { plant population. }\end{array}$ & Basnet et al., 1993 \\
\hline
\end{tabular}


Table 3 Cont......

\begin{tabular}{|c|c|c|c|c|c|}
\hline Finger millet & $\begin{array}{l}\text { Crop and nutrient management } \\
\text { Plant population x variety } \\
\text { Dalle-1with } 750 \\
\text { thousands plant/ha } \\
\text { Local with } 1000 \\
\text { thousands plant/ha } \\
\text { Nutrient levels } \\
40: 20: 20 \mathrm{~kg} \\
\mathrm{~N}, \mathrm{P}_{2} \mathrm{O}_{5}, \mathrm{~K} 2 \mathrm{O} / \mathrm{ha} \\
60: 30: 20 \mathrm{~kg} \\
\mathrm{~N}, \mathrm{P}_{2} \mathrm{O}_{5}, \mathrm{~K} 2 \mathrm{O} / \mathrm{ha} \\
60: 40: 30 \mathrm{~kg} \\
\mathrm{~N}, \mathrm{P}_{2} \mathrm{O}_{5}, \mathrm{~K} 2 \mathrm{O} / \mathrm{ha}\end{array}$ & $\begin{array}{l}0.87 \\
1.63 \\
2.31 \\
2.70 \\
2.23\end{array}$ & $\begin{array}{l}\text { i) } \mathrm{N}_{2} \mathrm{P}_{2} \mathrm{O}_{5}, \mathrm{~K} 2 \mathrm{O} @ \\
40: 20: 20 \mathrm{~kg} / \mathrm{ha} \\
\text { ii) Plant population of } 250 \\
\text { thousands/ha for } \mathrm{HYV} \text { s and } \\
\text { higher population for local } \\
\text { cultivar }\end{array}$ & $\begin{array}{l}\text { i) Weeds seem to be the } \\
\text { major problem. } \\
\text { ii) Some cultivars showed } \\
\text { higher yields with low } \\
\text { plant population. }\end{array}$ & Basnet et al., 1993 \\
\hline Ground nut & $\begin{array}{l}\text { Varietal management } \\
\text { Local check } \\
\text { Spanish-XV } \\
\text { Florunner } \\
\text { Florida 416-2 } \\
\text { AH-144 }\end{array}$ & $\begin{array}{l}1.09 \\
2.40 \\
2.56 \\
3.30 \\
4.0\end{array}$ & $\begin{array}{l}\text { i) Reproductive efficiency is } \\
\text { high }(10.0) \text { at } 40 \mathrm{~cm} \times 20 \mathrm{~cm} \\
\text { and lower }(3.6) \text { at } 30 \mathrm{~cm} \times 20 \\
\text { cm spacings } \\
\text { ii) } 20: 40: 20 \mathrm{~kg} / \mathrm{ha} \mathrm{N}, \mathrm{P}_{2} \mathrm{O}_{5} \text {, } \\
\mathrm{K}_{2} \mathrm{O}\end{array}$ & $\begin{array}{l}\text { Some cultivars produced } \\
\text { fewer flowers and fewer pegs } \\
\text { resulting in lower yields. }\end{array}$ & $\begin{array}{l}\text { Rajbhandari et al., 1993; } \\
\text { Rajbhandari and } \\
\text { Mishra, } 1987\end{array}$ \\
\hline \multirow[t]{2}{*}{ Soybean } & $\begin{array}{l}\text { Varietal management } \\
\text { Cobb } \\
\text { P-26 }\end{array}$ & $\begin{array}{l}2.06 \\
1.96\end{array}$ & $\begin{array}{l}\text { i) Plant population of } 3,33,000 \\
\text { ii) } \mathrm{N}, \mathrm{P}_{2} \mathrm{O}_{5}, \mathrm{~K}_{2} \mathrm{O} @ 30: 30: 20 \mathrm{~kg} / \\
\mathrm{ha}\end{array}$ & $\begin{array}{l}\text { Six genotypes including } \\
\text { ESSEX and CRAWFORD } \\
\text { had poor germination/ } \\
\text { viability percent resulting in } \\
\text { lower yields. }\end{array}$ & Gupta, 1985 \\
\hline & $\begin{array}{l}\text { Crop management } \\
\text { Hardee } \\
\text { P-28 } \\
\text { Bragg } \\
\text { Cobb. }\end{array}$ & $\begin{array}{l}1.16 \\
2.28 \\
2.44 \\
2.38\end{array}$ & $\begin{array}{l}\text { Timely sowing from last week of } \\
\text { May to June } 15\end{array}$ & $\begin{array}{l}\text { i) Flower abortion and low } \\
\text { pod setting; } \\
\text { ii) Delayed sowing from July } \\
27 \text { to August } 13 \\
\text { drastically } \\
\text { reduced yield }\end{array}$ & $\begin{array}{l}\text { Sharma, 1985; } \\
\text { Sharma, } 1987\end{array}$ \\
\hline \multirow[t]{2}{*}{ Mung bean } & $\begin{array}{l}\text { Sowing date and crop geometry } \\
\text { April } 16 \text { sowing with } \\
30 \mathrm{~cm} \times 5 \mathrm{~cm} \text { spacing } \\
\text { March } 2 \text { sowing } \\
\text { with } 30 \mathrm{~cm} \times 5 \mathrm{~cm} \\
\text { spacing }\end{array}$ & $\begin{array}{l}0.37 \\
1.06\end{array}$ & $\begin{array}{l}\text { i) Plant population of 3,33,000 } \\
\text { ii) } \mathrm{N}_{2} \mathrm{P}_{2} \mathrm{O}_{5}, \mathrm{~K}_{2} \mathrm{O} @ 20: 40: 30 \mathrm{~kg} / \\
\text { ha } \\
\text { iii) Insecticide B.H.C.@ } 20 \mathrm{~kg} / \mathrm{ha} \\
\text { applied to soil }\end{array}$ & $\begin{array}{l}\text { i) Delayed sowing from } \\
\text { April } 1 \text { to } 16 \text { drastically } \\
\text { reduced yield } \\
\text { ii) Crop geometry of } 45 \text { and } \\
60 \mathrm{~cm} \text { spacings showed } \\
\text { less plant population, } \\
\text { resulting in low yield } \\
\text { iii) Non-synchronize } \\
\text { maturity }\end{array}$ & Yadav et al., 1985 \\
\hline & 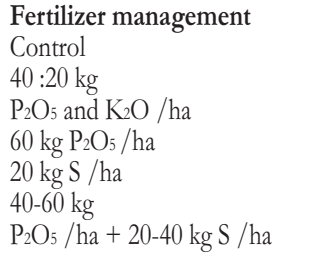 & $\begin{array}{l}0.25 \\
0.60 \\
0.80 \\
0.77 \\
0.65-0.77\end{array}$ & $\begin{array}{l}\text { i) } \mathrm{N} @ 20 \mathrm{~kg} / \mathrm{ha} \text {, Pusa Baisakhi } \\
\text { cultivar sown under upland } \\
\text { conditions in June } \\
\text { ii) spacing of } 30 \mathrm{~cm} \times 20 \mathrm{~cm}\end{array}$ & $\begin{array}{l}\text { i) Rainfed } \\
\text { ii) Indeterminate cultivar, } \\
\text { non-synchronized maturity } \\
\text { iii) Picking pods quite } \\
\text { cumbersome }\end{array}$ & $\begin{array}{l}\text { Yadav and Shrestha, } \\
\text { 1993; } \\
\text { Sah et al., } 1989\end{array}$ \\
\hline Cowpea & $\begin{array}{l}\text { No defoliation but } \\
\text { insecticide (Dimethoate } \\
0.025 \% \text { ) / Rogor } 25 \% \mathrm{EC} \\
\text { No defoliation } \\
16.6 \% \text { defoliantion } \\
\text { Complete defoliation }\end{array}$ & $\begin{array}{l}0.76 \\
0.75 \\
0.22\end{array}$ & $\begin{array}{l}\text { Removal of leaves by } 16.6 \% \text { but } \\
\text { with spraying of insecticide }\end{array}$ & $\begin{array}{l}\text { i) The crop was severely } \\
\text { affected by pod borers } \\
\text { and aphids } \\
\text { ii) The } \mathrm{N} \text { from the green } \\
\text { leaves could not transfer } \\
\text { to sink }\end{array}$ & $\begin{array}{l}\text { Timsina and Thapa, } \\
1991\end{array}$ \\
\hline
\end{tabular}

\section{Soil management}

Soil management research focused on tillage, straw mulch and management of macro- and micro-nutrients. The conventional tillage with timely intercultural operation produced an average yield of $3.32 \mathrm{t} / \mathrm{ha}$, significantly higher than all other tillage practices (Sharma et al., 1985). Maize yield in minimum tillage plot with one ploughing 
was $2.56 \mathrm{t} / \mathrm{ha}$ and was significantly higher than minimum tillage without ploughing $(0.57 \mathrm{t} / \mathrm{ha})$ and no tillage $(0.18 \mathrm{t} / \mathrm{ha})$. Other results indicated that conventional tillage with straw mulch resulted in taller plants with longer ear and higher yield, followed by tillage with no residue incorporation (Khadka and Sah, 1993). KhatriChhetri and Schulte (1985a; b) reported yield increments in maize due to added secondary and micro-nutrients over NPK treatments without micro-nutrients. They also reported that the soils of IAAS were deficient in N, $\mathrm{Zn}, \mathrm{Fe}, \mathrm{B}$, and Mo.

\section{Weed management}

Weed management study mostly concentrated on weed ecology and weed identification. Dangol and Gurung (1989) reported a total of 69 species of angiosperms associated with summer maize. The major families of weeds prevalent in summer maize were the Gramineae (13 spp), Compositae (9 spp), Euphorbiaceae and Cyperaceae (each with $7 \mathrm{spp}$ ), and Leguminoseae and Commelinaceae (each with $4 \mathrm{spp}$ ), while the major genus was Cyperus (5 species). The six dominant weeds based on the summed dominance ratio (SDR) were Echinocbloa colona (L.) Link (14.6), Brachiara ramosa (L.) Stapf (12.9), Cyperus. iria L. (6.1), Bulbostylis barbata L. (6.0), Commelina benghalensis L. (5.6) and Cynodon dactylon (L.) Pers. (5.6).

\section{Pest management}

Neupane et al. (1983) reported that on the basis of insect affected plants and percent-infested plants, early planting prior to 14 May resulted in higher infestation and more subsequent injury from the maize borer than planting on 24 May.

\section{Finger millet (Eleusine coracana L.)}

\section{Crop and nutrient management}

Basnet et al. (1993) reported that nitrogen was the main element contributing to higher yield in finger millet. It produced maximum yield (2.26 t/ha) at $60 \mathrm{~kg} / \mathrm{ha} \mathrm{N}, 30 \mathrm{~kg} / \mathrm{ha}$ of $\mathrm{P}_{2} \mathrm{O}_{5}$ and $20 \mathrm{~kg} / \mathrm{ha}$ of $\mathrm{K}_{2} \mathrm{O}$, and that sole application of $\mathrm{K}_{2} \mathrm{O} @ 30 \mathrm{~kg} /$ ha did not have any beneficial effect on the growth and development of the crop. The yield attributing components (number of tillers/plant, number of panicles/plant and panicle weight) were higher at low (250 thousands/ha) compared to high (500 thousands/ha) plant populations. Dalle-1 (750 thousand plants/ha) and a local variety (1000 thousand plants/ha) provided higher yields over other varieties. The local variety exceeded the yield of Dalle-1 by $80 \%$.

\section{Groundnut (Arachis bypogeae L.)}

\section{Varietal management}

Rajbhandari et al. (1993) observed that the groundnut genotypes, AH-144, AC-343, AC-15729, AC-17257, Florunner and 3167-74 M, were of short duration at Rampur. Those genotypes also did not exhibit excessive vegetative growth during seed formation and thus appeared to be the best suited. They also reported that the yields of groundnut varieties AC-343, Spanish- XV, Florida 416-2, Florunner and AH-144 were 2360, 2400, 3333,2587 and $4000 \mathrm{~kg} / \mathrm{ha}$, respectively, with the crop geometry of $40 \times 20 \mathrm{~cm}^{2}$ and $\mathrm{N}, \mathrm{P}_{2} \mathrm{O}_{5}$ and $\mathrm{K}_{2} \mathrm{O}$ of 20 , 40 , and $20 \mathrm{~kg} / \mathrm{ha}$, respectively. Other research findings revealed that groundnut genotypes could be grouped into three classes based on the growth duration: early (100-115 days), medium (116-130 days) and late (131-150 days) maturing. Early maturing genotypes, AH-144 and Florunner, surpassed the yield of local check (1.09 t/ ha) by 266 and 137\%, respectively, higher than that of medium maturing genotypes, Florida 416-2 and SpanishXV (205 and 120\% more yielding over the local check) (Rajbhandari and Mishra, 1987).

\section{Soybean (Glycine max L.)}

\section{Varietal evaluation}

A study on disease management for different soybean cultivars at Rampur indicated that the exotic cultivars of soybean had poor germination and low plant vigor. The local variety P-28 scored the lowest damage (13\%) compared to most of the varieties (Gunter, AGS-144, G2261 etc.) tested, with damage ranging from 2.1 to $21 \%$ (Thapa and Timsina, 1992). Another study (Gupta, 1985), also at IAAS Rampur, reported that Cobb and P-26 were the top yielding cultivars amongst the sixteen soybean cultivars tested. The higher yields for those cultivars were due to higher seed weight and higher number of pods per plant apart from greater germination rate. Six genotypes including ESSEX and CRAWFORD had poor germination/viability percentage resulting in lower 
yield. In another study also, field performance of 16 genotypes from maturing groups V to VIII revealed higher yields than from cultivars belonging to early maturing group, and those yields were attributed to more pods/ plant and more seeds/pod (Sharma, 1983). In still another study, large seeded brown, medium seeded black and small seeded white cultivars were the main cultivars grown either in the mixed and/or relay crop with maize and millet in hilly regions of Nepal (Sharma, 1994). That study also identified the need for exploitation of local germplasm, improvement in production practices for yield increment, and establishment of soybean processing industries. In another study (Sharma et al., 1990), 63 determinate soybean genotypes were tested for seeds produced on terminal nodes (STN), and length (LTR), weight (W'TR) and thickness (RTH), flowers (FTR), pods (PTR) and seeds (STR) of terminal raceme, percent of total pods at 1-5, 6-10, and above 10 floral positions on terminal raceme. LTR and RTH showed positive correlation with STN, FTR, PTR, and STR. The results further suggested that flower abortion and pod set at various floral positions on terminal raceme were genotypic characteristics controlled via raceme thickness. Another field study on the genotype and canopy section interaction for flower production and abortion, pod set, and seed yield of determinate and indeterminate genotypes indicated that indeterminate genotypes produced higher proportion of flowers at bottom section of the canopy when compared to determinate genotypes (Sharma et al., 1991). In that study, whole plant was divided into four sections each containing equal number of flowering nodes. Sections I and IV represented the bottom and top whereas II and III were the middle sections. Branches from the nodes at different canopy levels of the main stem were included into respective sections. Significant genotype x canopy section interaction was observed for number of flowers, pod set, and seed yield. Flower abortion was progressively increased towards the top of the canopy. The productivity of nodes across soybean canopy was more dependent on the number of flowers produced than on the level of flower abortion at various sections.

\section{Crop management}

Two studies on crop management were conducted at Rampur, one of which was on the date of planting and another on the nodulation pattern. The former showed that delay in planting from May 28 to July 27 significantly reduced the seed yield of P-28 and Hardee but not of Bragg and Cobb at Rampur. Seed yields of all cultivars were further reduced to $50 \%$ as planting was delayed from July 27 to August 13 . Sharp reduction in yield for planting beyond July 27 was attributed to cultivar sensitivity to critical photoperiod, inducing early flowering and short grain-filling period (Sharma, 1985). In the latter study, Sharma (1987) noted that seed germination, plant height, shoot weight, and root weight decreased with increasing levels of inoculum; however, the magnitude of reduction varied with cultivars.

\section{Mungbean (Vigna radiata L.)}

\section{Varietal evaluation}

Thapa and Timsina (1992) reported that exotic cultivars of mungbean (CESU-1, IPB M79-13-29, etc.) were better in all agronomical characters (pod/branch, pod length, test weight etc.) than the local check (Local mung), though the severe incidence of mungbean flies was noted on all the exotic lines. At 6 weeks age stage, almost all the plants were damaged by mungbean flies, with damage ranging from $63 \%$ in the local cultivar to $78-79 \%$ in the exotic ones. In another study, mungbean sown on March 2 with $30 \mathrm{~cm}$ row spacing gave the highest yield (1.06 t/ha) and significantly reduced when sown after March 2. Yield differences due to variations in spacing were significant with higher yields for higher population (Yadav et al., 1985).

\section{Fertilizer management}

Yadav and Shrestha (1993) reported that the mungbean cultivar, Pusa Baisakhi, produced the highest seed yield $(0.60 \mathrm{t} / \mathrm{ha})$ with $40 \mathrm{~kg} \mathrm{P}_{2} \mathrm{O}_{5} / \mathrm{ha}$ and $20 \mathrm{~kg} \mathrm{~K} \mathrm{O}_{2} / \mathrm{ha}$. Other results at Rampur revealed that the grain yield of mungbean increased from 0.50 to $0.80 \mathrm{t} / \mathrm{ha}$ with the application of $60 \mathrm{~kg} \mathrm{P} \mathrm{O}_{5} / \mathrm{ha}$ alone and from 0.69 to $0.77 \mathrm{t} / \mathrm{ha}$ with the application of $20 \mathrm{~kg} \mathrm{~S} / \mathrm{ha}$ alone. The combined application of $\mathrm{P}_{2} \mathrm{O}_{5}$ and $\mathrm{S}$ at 20 and $40 \mathrm{~kg} /$ ha respectively increased its yield significantly over control (Sah et al., 1989).

Cowpea (Vigna unguiculata L. Walp)

\section{Varietal evaluation}

Timsina (1990) reported that amongst the 7 early maturing, 17 medium maturing and 13 vegetable type cowpea varieties tested for upland, two varieties from early maturing group (IT- $82 \mathrm{E}-18$ (0.95 t/ha), and IT- 
82E-18 (0.99 t/ha)), two from vegetable type (IT 81D-1228-15 and IT-81D-1228-10) (9.51t/ha and 9.63 t/ha green pods, respectively), and three from medium maturing type (IT-82D-716, IT81D-1137 and TVX 466107E) $(1.01 \mathrm{t} / \mathrm{ha}, 1.16 \mathrm{t} / \mathrm{ha}$ and $0.94 \mathrm{t} / \mathrm{ha}$, respectively)) produced significantly higher yields as compared to other improved varieties and a local check. Cowpea varieties were also tested with various intensities of defoliation under field conditions at Rampur. Removal of leaves by $16.6 \%$ but with insecticide application (Dimethoate $0.025 \%$ increased the grain yield nearly by $90 \%$ as compared to no defoliation and no insecticide application. However, defoliation by $50 \%$ or more decreased grain yield to a greater extent and also delayed maturity as compared to low levels of defoliation (Timsina and Thapa, 1991).

\section{Winter season crops}

\section{Wheat (Triticum aestivum L.)}

\section{Varietal evaluation}

The varietal evaluation studies in wheat were primarily focused on varietal evaluation under various sowing dates. A varietal evaluation study under various sowing dates showed that NL-539 was better for both timely (15 November) and late sown (after 10 December) conditions. Other varieties, NL-251, BL-1135 and Annapurna, had comparatively higher grain yield, higher grain filling rate, and longer grain filling periods for timely-sown conditions whereas UP-2121, UP-262, RR-21 and BL-1135 gave higher yield with higher grain filling rate for late-sown conditions (Chaudhary et al., 1994). Adhikari and Sharma (2000) reported that, for the 24 wheat genotypes tested, sterility in wheat ranged from 1.4 to $31.8 \%$ with most varieties having sterility less than $15 \%$. Sharma and Chaudhary (1988) observed that amongst the 15 wheat genotypes, a tall cultivar Lerma-52 had more number of tillers $\left(379 / \mathrm{m}^{2}\right)$, nodes/tiller (5.6), leaves/tiller (8.4) and a longer vegetative growth period (77 days) in contrast to RR-21, a semi-dwarf variety, which had fewer tiller numbers $\left(168 / \mathrm{m}^{2}\right)$ and a shorter vegetative growth period (63 days). In another experiment with 10 genotypes, dry matter accumulation between 60 and 76 days after seeding effectively represented final biomass yield, and that biomass yield, harvest index, and grain filling period had significant positive correlations with grain yield (Sharma, 1993a). Sharma et al. (1993c) also reported that biomass yield, harvest index, kernel weight, and durations for the vegetative growth (VGP) and grain filling (GFP) were related to the grain yield. Nepal (1980) previously reported that wheat cultivars UP-262 and Nacazori-76 produced significantly higher yields than RR-21, NL-281 and HP1267 , and also exhibited the considerable tolerance to lodging and brown rust disease.

Another varietal evaluation study, also at Rampur, involved the testing of wheat lines from Nepal, Bangladesh and Philippines with varying levels of tolerance to Helminthosporium leaf blight (HLB). Results revealed that various wheat lines differed significantly for days to heading and maturity, plant height, tiller number, grain yield, area under disease progress curve (AUDPC), and the highest disease score (HDS). There was also a weak negative correlation between yield and AUDPC $(\mathrm{r}=-0.20)$ and HDS $(\mathrm{r}=-0.40)$ (Sharma et al., 1994).

Five wheat genotypes, each from short, medium and long coleoptile groups, were evaluated to determine the effect of coleoptile length on stand establishment and yield performance (Sharma, 1990). The initial seedling number was higher for the long coleoptile group, whereas grain yield was higher for the short coleoptile group. As such, longer coleoptile failed to show any advantage in terms of crop stand and performance. To determine the inheritance of root and associated shoot development in wheat, a replicated experiment was conducted including seven F1 crosses involving five genetically diverse wheat parents in plastic tubes using vermiculite growth medium in a green house. Results showed the weak growth for the longest root and the longest leaf recorded for four weeks. The phenomena of additive genetic mechanism, and partial and complete dominance were also present (Sharma, 1991). Studies undertaken on the general combining ability (GCA), specific combining ability (SCA), ability of the parents and their hybrid progenies, and on the correlations of grain filling period (GFP) with various agronomic traits showed that eight parents differed for GFP. The GCA effect was significant for GFP, whereas the SCA effect was non-significant. The parents Bl-1022, Nepal 251, and UP-262 were superior with positive GCA estimates and longer GFP than other parents. The correlations of GFP with other traits indicated that improvement in GFP should also improve grain yield, harvest index and kernel weight (Sharma, 1992). The maximum biomass yield $(9.62 \mathrm{t} / \mathrm{ha})$, grain yield $(3.93 \mathrm{t} / \mathrm{ha})$, and harvest index $(41.1 \%)$ coincided with the 25 November seeding and the longer GFP was associated with higher grain yield only for some genotypes. A varietal study with 10 genotypes under four sowing dates (Sharma, 1993b) revealed that the 
average change due to delayed seeding from 10 November to 25 December was six days for VGP, 25 days for GFP, and 31 days for the total crop duration period (CDP). Biomass yield and grain yield were reduced by 2.7 and $1.21 \mathrm{t} / \mathrm{ha}$, respectively, due to delayed seeding, while harvest index was reduced by $4.1 \%$. The effect of delayed seeding was more pronounced on GFP than the VGP causing reduction in CDP to be due primarily to reduced GFP. More emphasis on GFP within CDP, especially under the late seeding, should be attempted to obtain high yield.

\section{Crop management}

The crop management study on wheat was conducted to identify the optimum seed rate and irrigation management. Sharma (1987) reported that the seed rate affected the grain yield, tiller number, grains/spike, 1000 kernel weight, days to heading, and plant height at harvest. For both reduced and higher seed rates than the recommended $(120 \mathrm{~kg} / \mathrm{ha})$, there was an adverse effect on all the above-mentioned traits. The effect of dew on wheat yield and soil water balance at Rampur showed that grain yield was significantly higher for irrigated treatment $(4.02 \mathrm{t} / \mathrm{ha})$ followed by rainfed $(3.03 \mathrm{t} / \mathrm{ha})$, dew $(2.60 \mathrm{t} / \mathrm{ha})$ and control $(2.58 \mathrm{t} / \mathrm{ha})$ treatments. The moisture meter readings and soil moisture content analysis also showed that dew did not significantly contribute to the evapo-transpiration requirement of wheat (Sharma et al., 1984).

\section{Soil management}

Under soil management studies in wheat, different tillage practices/land preparation methods, and balanced fertilization were evaluated. Pandit et al. (1993) reported that there was a significant effect of tillage on clod size distribution and soil moisture at different growth stages of wheat. Mould board ploughing + single harrowing resulted in maximum yield $(0.73 \mathrm{t} / \mathrm{ha}$ ), while two ploughings with indigenous plough + one planking produced the lowest yield $(0.48 \mathrm{t} / \mathrm{ha})$. The other land preparation methods, such as disk ploughing + single harrowing, or only single or double harrowings produced intermediate yields. Another experiment with the application of pre-plant wheel compaction, chiseling, and farmyard manure (FYM) reported that compaction significantly increased bulk density and decreased hydraulic conductivity as compared to non-compacted soil, and that chiseling and FYM@16 t/ha alleviated the effect of compaction (Adhikari, 1998-99).

Yadav et al. (1994) reported the highest grain yield (2.83 t/ha) with application of N, P, K, S and micronutrients. The effect of lime application on acidic soils of Rampur indicated that Dolomite is preferred to Calcite, and Dolomite had significant effect on soil reaction and grain yield (Adhikari et al., 1993). The increments in grain yield were attributed to the greater availability of nutrient elements due to indirect increment in soil $\mathrm{pH}$. About $0.5 \mathrm{t} / \mathrm{ha}$ of lime produced the highest grain yield in the sandy loam soil in the west Chitwan valley, while the clay loam in the east Chitwan valley required $2.0 \mathrm{t} / \mathrm{ha}$ lime to produce the same yield (Adhikari, 1995). It indicates that the acidity of Chitwan soils can be alleviated and wheat yield improved by applying appropriate amounts of lime. In another study, Chaudhary et al. (1985) noted that the response of wheat to Zn application was non-significant, however, the $\mathrm{P}$ application increased the grain yield.

\section{Weed management}

Weed management study in wheat was mainly focused on weed identification. The weed survey in Chitwan and Parsa districts indicated the dominance of about 35 weed species representing 33 genera and 16 families (Dangol and Chaudhary, 1994). The major families of weeds were Asteraceae, Fabaceae and Poaceae, and dominant weed species were Gnaphalium luteo-album L., Chenopodium album L., Cynodon dactylon (L.) Pers., Equisetum debile Roxb. ex Voucher, Lathyrus aphaca L., Anagalis arvensis L., Rumex dentatus L. Lolium temulentum L, Digitaria adscendens(HBK.) Henr., and Polygonum plebeium R. Br.. The allelopathic effects of aqueous extracts of Fumaria indica/parviflora (Houssk.) Pugsley, Ageratum houstonianum Mill. and Rotala indica (Willd.) Koehne were also investigated on wheat seed germination and seedling growth. Other research results further revealed that the highest yield $\left(3.5 \mathrm{t} / \mathrm{ha}\right.$ ) was obtained from weed free plots when sown on $28^{\text {th }}$ November (Chaudhary et al, 1988). 
Table 4. Major technologies tested in various wheat-based research at IAAS, Rampur, Chitwan

\begin{tabular}{|c|c|c|c|c|}
\hline Technologies tested & $\begin{array}{l}\text { Yield } \\
\text { range (t/ha) }\end{array}$ & $\begin{array}{l}\text { Optimum cultural } \\
\text { practice }\end{array}$ & Characteristics/constraints & Source/ References \\
\hline $\begin{array}{l}\text { Varietal management } \\
\text { i) NL-539 } \\
\text { ii) NL-251, BL-1135 } \\
\text { and Annapurna } \\
\text { iii) UP-2121, UP-262, } \\
\text { RR-21 and BL-1135 } \\
\text { iv) UP-262 and } \\
\text { Nacazori-76 } \\
\text { v) Lerma-52 (tall cultivar) }\end{array}$ & $\begin{array}{l}2.18 \\
1.70-2.08 \\
1.71-1.97 \\
3.20\end{array}$ & $\begin{array}{l}\text { Cultivars sown for } \\
\text { early and late sown conditions } \\
\text { Cultivars sown on } 15 \text { November } \\
\text { Cultivars sown on } 10 \text { December } \\
\text { Tolerance to lodging and } \\
\text { brown rust } \\
\text { Lerma- } 52 \text { recorded more } \\
\text { tillers }\left(379 / \mathrm{m}^{2}\right) \text {, nodes/tiller } \\
\text { (5.6), leaves/tiller (8.4) and a } \\
\text { longer vegetative growth period } \\
\text { (77 days) compared to } \\
\text { other cultivars }\end{array}$ & $\begin{array}{l}\text { i) Amongst the } 24 \\
\text { genotypes studied, majority } \\
\text { had sterility less than } 15 \% \\
\text { ii) RR-21, a semi-dwarf variety, had } \\
\text { fewer seedling numbers }\left(168 / \mathrm{m}^{2}\right) \\
\text { and a shorter vegetative growth } \\
\text { period ( } 63 \text { days) resulting in } \\
\text { lower yield } \\
\text { iii) Dry matter accumulation between } \\
60 \text { and } 76 \text { days after seeding } \\
\text { effectively represented final } \\
\text { biomass yield, and that } \\
\text { biomass yield, harvest index, and } \\
\text { grain filling period had } \\
\text { significant positive } \\
\text { correlation with grain yield. }\end{array}$ & $\begin{array}{l}\text { Chaudhary et al., 1994; } \\
\text { Adhikari and Sharma, 2000; } \\
\text { Nepal, 1980; }\end{array}$ \\
\hline $\begin{array}{l}\text { Crop management } \\
\text { Irrigated } \\
\text { Rainfed } \\
\text { Dew } \\
\text { Control }\end{array}$ & $\begin{array}{l}4.02 \\
3.03 \\
2.6 \\
2.58\end{array}$ & $\begin{array}{l}2 \text { irrigations at CRI } \\
\text { and heading under } \\
\text { irrigated plot. }\end{array}$ & $\begin{array}{l}\text { The dew could not complete } \\
\text { the water } \\
\text { requirement of wheat }\end{array}$ & Sharma et al., 1984 \\
\hline $\begin{array}{l}\text { Soil management } \\
\mathrm{NPK}+\mathrm{S}+\mathrm{B}\end{array}$ & 2.83 & $\begin{array}{l}\text { i) Sandy loam- } \\
0.5 \mathrm{t} \text { lime } / \mathrm{ha} \\
\text { ii) Clay loaml- } 2.0 \mathrm{t} \\
\text { lime / ha } \\
\text { iii) Dolomite preferred } \\
\text { to calcite }\end{array}$ & $\begin{array}{l}\text { i) The pot culture experiment } \\
\text { should be conducted in the field also } \\
\text { ii) Micronutrients, especially Bo } \\
\text { and } \mathrm{Zn} \text {, seemed to be deficient }\end{array}$ & $\begin{array}{l}\text { Yadav et al., } 1994 \\
\text { Adhikari, 1995; } \\
\text { Adhikari et al., } 1993\end{array}$ \\
\hline $\begin{array}{l}\text { Weed management } \\
\text { Weed-free plot } \\
\mathrm{N} @ 90 \mathrm{~kg} / \mathrm{ha}+ \\
\text { Methabenzthiazuron@ } \\
1.5 \mathrm{~kg} \text { a.i./ ha } \\
\mathrm{N} @ 60 \mathrm{~kg} / \mathrm{ha}+2, \\
4-\mathrm{D} @ 0.75 \mathrm{~kg} \text { a.i./ha } \\
\mathrm{N} @ 90 \mathrm{~kg} / \mathrm{ha}+\text { Isoproturon } \\
\text { @ } 1.5 \mathrm{~kg} \text { a.i./ ha } \\
\text { Control }\end{array}$ & 2.8 & Wheat sown on $28^{\text {th }}$ November & $\begin{array}{l}\text { The major families of weeds } \\
\text { in wheat were Asteraceae, } \\
\text { Fabaceae and Poaceae }\end{array}$ & $\begin{array}{l}\text { Chaudhary et al., 1988; } \\
\text { Dangol and Chaudhary, } 1994\end{array}$ \\
\hline
\end{tabular}

\section{Storage pest management}

Panthee (1996-97a) tested the quality assessment of wheat seed stored in different storage structures for eight months at Rampur and Lumle, and reported that jute bag with inner plastic lining and aluminum bins were the best storage structures. Another experiment showed that bojho (Acorus calamus L.) was more effective than Malathion, whereas titepati (Artemisia vulgaris L.) and timur (Zanthoxylum sp.) were ineffective against all storage pests (Panthee, 1996-97b).

\section{Buckwheat (Fagopyrum esculentum Moench.)}

\section{Varietal evaluation}

Rajbhandari (1991) reported that amongst the seven ecotypes of common buckwheat, the ecotypes introduced from different hill districts varied in morphological growth stages. The analysis of variability and co-relation coefficients revealed higher genotypic variability in terms of test weight and leaf area, and strong positive effect of these characters on grain yield. Results indicated the differences in phenology, dry matter production and partitioning, and crop growth rate for various ecotypes. Both temperature and precipitation influenced flowering and the seed development pattern. Another experiment on the response of local buckwheat cultivars to various crop geometry revealed that a plant spacing of $15 \mathrm{~cm} \times 5 \mathrm{~cm}$ was found to be optimum for buckwheat for humid sub-tropical climate of Rampur (Rajbhandari and Mishra, 1993). 


\section{Rapeseed (Brassica campestris L.) and mustard (Brassica juncea Czern. and Coss.)}

\section{Crop management}

Crop management studies on rapeseed and mustard were mainly concentrated on the identification of optimum sowing date, seed rate and sowing methods, and on the effect of pesticides on yield. Sowing rape on 24 October showed significant superiority in terms of yield (1.1 t/ha) over sowing on 31 October $(1.0 \mathrm{t} / \mathrm{ha})$ and 7 November $(0.9 \mathrm{t} / \mathrm{ha})$. The results further indicated that yield potential of each of the rape genotypes would drastically be reduced with subsequent delay in seeding after second week of November (Mishra et al., 1994; 1995). Of the three sowing dates, the earliest sowing (24 October) had also the maximum number of aphids. For all the dates of sowing, Methyl demeton and Phosphomidon provided significant control of aphids over Dichlorophos and Monocrotophos applications. Another study concluded that rape crop sown on 24 October with two sprays of Metasystox @ 0.025\% gave the highest yield (Pandey, 1977).

Sah and Mishra (1995) reported that the higher seed rates (10 and $12 \mathrm{~kg} / \mathrm{ha})$ for rape and mustard reduced the number of siliqua/plant, number of seeds/siliqua, 1000 seed weight, and seed yield. Broadcasting method of sowing seed produced the highest seed yield $(0.50 \mathrm{t} / \mathrm{ha})$, while increased spacing $(50 \mathrm{~cm} \times 20 \mathrm{~cm})$ decreased the yield $(0.35 \mathrm{t} / \mathrm{ha})$. The yield of broadcast-sown rapeseed was significantly superior to sowing with $50 \mathrm{~cm}$ spacing but was at par with 30 and $40 \mathrm{~cm}$ spacing.

\section{Soil and weed management}

Soil and weed management studies were conducted to see the combined effect of nitrogen fertilizer with the micro-nutrients and herbicides (Chaudhary et al, 1993b). The study revealed that nitrogen @60 kg/ha, in combination with Fluchloralin and Pendimethalin, both@0.5 kg/ha, produced yields of $1.06 \mathrm{t} / \mathrm{ha}$ and $1.15 \mathrm{t} /$ ha of tori and sarson, respectively. Other $\mathrm{N}$ and $\mathrm{S}$ interaction study (Sah et al., 1985) revealed that sole application of $\mathrm{N}$ had no effect on yield, but of $\mathrm{S}$ had an effect. The combined application of $50 \mathrm{~kg} / \mathrm{ha}$ each of $\mathrm{N}$ and $\mathrm{S}$ produced the highest yield $(0.63 \mathrm{t} / \mathrm{ha})$ followed by that with $30 \mathrm{~kg} \mathrm{~N}$ and $60 \mathrm{~kg} \mathrm{~S} / \mathrm{ha}(0.62 \mathrm{t} / \mathrm{ha})$. This might mainly be due to the increased seed weight and number of siliqua/plant. $\mathrm{N}$ had no effect on the seed oil content, but $\mathrm{S}$ singly, as well as in combination with $\mathrm{N}$, increased the oil content.

A weed susceptibility study with various oilseed crops (Chaudhary, 1995) showed that Brassica campestris var. toria L. (Toria), B. campestris var. sarson L. (Sarsoon), B. juncea L. (Rayo), Nicotiana tabacum L. (Tobacco) and B. juncea var. rugosa L. (Broadleaved mustard) were found highly susceptible to orobanche infestation, whereas B. oleracea var. botrytis L. (Cauliflower), B. oleracea var. capiata L. (Cabbage), Lycopersicon esculentum Mill. (Tomato) and Solanum melongena L. (Eggplant) were less susceptible. Vicia faba L. (Fababean), Cicer arietinum L. (Chickpea), Lens esculenta Moench (Lentil), Pisum sativum var. arvense L. (Pea), Daucus carota L. (Carrot), Solanum tuberosum L. (Potato) and Capsicum annum L. (Pepper) were, however, found to be free from orobanche infestation.

Potato (Solanum tuberosum L.)

\section{Crop management}

The crop management study on potato was focused on the identification of shape and size of tubers for planting and methods of land preparation. Khairgoli (1982) reported that the yield response to size in potato was in the descending order: $60 \mathrm{~g}$ whole tuber $>60 \mathrm{~g}$ cut tuber $>30 \mathrm{~g}$ whole tuber $>30 \mathrm{~g}$ cut tuber $>15 \mathrm{~g}$ whole tuber $>15 \mathrm{~g}$ cut tuber. Thus, increment in seed weight increased the yield. Freshly cut half tuber but with equivalent weight with full tuber had lower yield than the whole tuber. Shrestha and Dhakal (1981) reported that seeds with four sprouts, planted in the furrow and earthing up, resulted in the highest yield (25.4 t/ha). Furrow and flat methods were superior to the ridge planting for improved emergence and increased tuber number, however, the weight/hill was significantly higher in the ridge planting $(0.70 \mathrm{~kg} / \mathrm{hill})$.

\section{Fertilizer management}

A fertilizer management study at Rampur (Gurung et al., 1977) showed that the application of $\mathrm{N}$ and $\mathrm{P}$ significantly increased the tuber yield of potato, but not the application of $\mathrm{K}$. The response of potato to $\mathrm{N}$ and $\mathrm{P}$ was quadratic. The optimum dose of $\mathrm{N}$ was $63.7 \mathrm{~kg} / \mathrm{ha}$ with a benefit cost ratio (BCR) of 6.6, while the BCR of $\mathrm{P}$ at $60 \mathrm{~kg} \mathrm{P}_{2} \mathrm{O}_{5} /$ ha was 6.3. Another study indicated that the increase in dry matter content of tubers was significantly prominent at lower level of fertilization (50:50:30 kg N: $\mathrm{P}_{2} \mathrm{O}_{5}: \mathrm{K}_{2} \mathrm{O} / \mathrm{ha}$ ), whereas for haulm and leaves, it attained the highest values with 150:150:90 kg N:P $\mathrm{O}_{5}: \mathrm{K}_{2} \mathrm{O} / \mathrm{ha}$. The tuber yield was also the highest 
(16.9 t/ha) with the highest levels of fertilizers (Basnet et al, 1998-99).

Weed management

A weed control study at Rampur (Gupta et al, 1977) showed that EPTC, Paraquat and Metobromuron, all three tested herbicides, controlled the weeds associated with potato during germination as well as during hilling up, and increased the potato tuber yield by $0.20-0.46 \mathrm{t} / \mathrm{ha}$ over the conventional practice. The results further indicated that pre-plant incorporation of EPTC at $15 \mathrm{~kg} / \mathrm{ha}$ proved to be the most remunerative.

Pest Management

Bhardwaj et al. (1981) concluded that Diathane M-45 (0.3\%), Diathane Z-78 (0.3\%) and Fytolan $(0.3 \%)$ sprayed thrice at an interval of 15 days after 40 days of sowing controlled the late blight disease by up to $78.7 \%$, $75.1 \%$ and $72.9 \%$, respectively, over control.

Lentil (Lens esculenta L.) and chickpea (Cicer arietinum L.)

Production constraints

Grain yields of chickpea and lentil were 1.80 and $1.76 \mathrm{t} / \mathrm{ha}$, respectively with the recommended package of practices at Rampur (Dahal et al., 2000). The recommended practices were 20, 40, and $20 \mathrm{~kg} \mathrm{~N}, \mathrm{P}_{2} \mathrm{O}_{5}$, and $\mathrm{K}_{2} \mathrm{O} /$ ha, respectively, $40 \mathrm{~kg}$ seeds/ha, 12 November sowing, one weeding at 40 DAS, 2 irrigations at flowering and pod setting, and 2 sprays of Decis @ $2.5 \mathrm{ml} /$ liter of water at early and late flowering stages. Survey findings concurrently conducted under the same study also revealed that both lentil and chickpea could be grown successfully in Chitwan, provided the optimum cultivation practices are followed.

Sunflower (Helianthus annuus L.)

\section{Varietal evaluation}

Dahal et al. (1993) reported a significant effect of sowing date on sunflower yield, with October planting producing significantly higher yield $(29.2 \mathrm{~g} /$ plant $)$ followed by May $(27.2 \mathrm{~g} /$ plant $)$ and February $(24.9 \mathrm{~g} / \mathrm{plant})$ plantings. The results further revealed that moisture deficiency was the major yield- limiting factor for the crop sown in February. Prevalence of insects and diseases was identified as one of the major constraints (especially for May planting) for the successful cultivation of sunflower at Rampur.

Table 5. Major technologies tested in various winter crops-based researches at IAAS, Rampur, Chitwan

\begin{tabular}{|c|c|c|c|c|c|}
\hline Crops & Technologies tested & $\begin{array}{l}\text { Yield range } \\
(\mathrm{t} / \mathrm{ha})\end{array}$ & Optimum cultural practices & Characteristics/constraints & Source/ References \\
\hline $\begin{array}{l}\text { Rape } \\
\text { seed and } \\
\text { mustard }\end{array}$ & $\begin{array}{l}\text { Optimum sowing date } \\
\text { October } 24 \\
\text { October } 31 \\
\text { November } 7\end{array}$ & $\begin{array}{l}1.1 \\
1.0 \\
0.9\end{array}$ & $\begin{array}{l}\text { The rapeseed sown on } 24 \text { th } \\
\text { October with two sprays of } \\
\text { Metasystox @ } 0.025 \% \text { gave the } \\
\text { highest yield. }\end{array}$ & $\begin{array}{l}\text { i) Availability of quality } \\
\text { seeds of rapeseed and } \\
\text { mustard on time. } \\
\text { ii) The optimum time of } \\
\text { sowing depends on the } \\
\text { monsoonal pattern. }\end{array}$ & $\begin{array}{l}\text { Mishra et al., 1994;1995 } \\
\text { Pandey, } 1977\end{array}$ \\
\hline & $\begin{array}{l}\text { Nutrient and weed } \\
\text { management } \\
\mathrm{N} \text { and S each @ } 50 \mathrm{~kg} / \mathrm{ha} \\
30 \mathrm{~kg} \mathrm{~N} \text { and } 60 \mathrm{~kg} \mathrm{~S} / \mathrm{ha} \\
\mathrm{N} @ 60 \mathrm{~kg} / \mathrm{ha}+\text { Fluchloralin } \\
\text { and Pendimethalin } \\
\text { both @ } 0.5 \mathrm{~kg} / \mathrm{ha} \text { (for tori) } \\
\mathrm{N} @ 60 \mathrm{~kg} / \mathrm{ha}+\text { Fluchloralin } \\
@ 0.5 \mathrm{~kg} / \mathrm{ha} \text { (for mustard) } \\
\mathrm{N} @ 60 \mathrm{~kg} / \mathrm{ha}+\text { Fluchloralin } \\
\text { @ } 0.5 \mathrm{~kg} / \mathrm{ha} \text { (for sarson) }\end{array}$ & $\begin{array}{l}0.63 \\
0.62 \\
1.60\end{array}$ & $\begin{array}{l}\text { Combined application of } \mathrm{N} \\
\text { and } \mathrm{S} \text { along with } 40 \mathrm{~kg} \mathrm{P}_{2} \mathrm{O}_{5} \\
\text { and } 30 \mathrm{~kg} \mathrm{~K} \mathrm{~K}_{2} \mathrm{O} \text { seemed better. } \\
\mathrm{N} @ 60 \mathrm{~kg} / \mathrm{ha} \text { in combination } \\
\text { with Fluchloralin and } \\
\text { Pendimethalin both @ } 0.5 \mathrm{~kg} / \\
\text { ha seemed better for tori. }\end{array}$ & $\begin{array}{l}\text { S devoicing plots recorded } \\
\text { the lowest yield of oilseed } \\
\text { and the oil content. } \\
\text { i) Herbicides not easily } \\
\text { available in markets } \\
\text { ii)Lack of technical } \\
\text { knowledge to use } \\
\text { herbicides }\end{array}$ & $\begin{array}{l}\text { Sah et al., } 1985 \\
\text { Chaudhary et al., 1993b }\end{array}$ \\
\hline
\end{tabular}


Table 5. Cont..........

\begin{tabular}{|c|c|c|c|c|c|}
\hline \multirow[t]{4}{*}{ Potato } & $\begin{array}{l}\text { Crop management } \\
\text { Tubers with four sprouts }\end{array}$ & 25.40 & $\begin{array}{l}\text { Planted in October in the } \\
\text { furrows and earthing up at } 45 \\
\text { DAS }\end{array}$ & $\begin{array}{l}\text { i) Ridge planting resulted in } \\
\text { fewer plants but higher } \\
\text { tuber yield / hill. } \\
\text { ii)Moisture stress and weed } \\
\text { infestation are the major } \\
\text { problems }\end{array}$ & $\begin{array}{l}\text { Shrestha and Dhakal, } \\
1981\end{array}$ \\
\hline & $\begin{array}{l}\text { Fertilizer management } \\
\text { 150:150:90 kg N: } \mathrm{P}_{2} \mathrm{O}_{5}: \mathrm{K}_{2} \mathrm{O} / \mathrm{ha}\end{array}$ & 16.89 & $\begin{array}{l}\text { October sown with } \\
\text { recommended cultural } \\
\text { practices }\end{array}$ & Late blight infestation & Basnet et al., 1998-99 \\
\hline & $\begin{array}{l}\text { Weed management } \\
\text { EPTC @ } 1.5 \mathrm{~kg} \text { a.i. } / \mathrm{ha} \text { in soil } \\
\text { applied herbicides } \\
\text { Paraquat } 0.75 \mathrm{~kg} \text { a.i. } / \mathrm{ha} \\
\text { Metobromuron } 1 \mathrm{~kg} \text { a.i. } / \mathrm{ha} \\
\text { Hand weeding twice } \\
\text { Conventional }\end{array}$ & $\begin{array}{l}14.8 \\
13.2 \\
9.8 \\
9.8 \\
7.2\end{array}$ & $\begin{array}{l}\text { EPTC as soil applied } \\
\text { herbicides seemed better to } \\
\text { control all species of weeds } \\
\text { with less environmental } \\
\text { pollution. }\end{array}$ & $\begin{array}{l}\text { i) Herbicides not easily } \\
\text { available in markets } \\
\text { ii) Lack of technical } \\
\text { knowledge to use } \\
\text { herbicides. }\end{array}$ & Gupta et al., 1977 \\
\hline & $\begin{array}{l}\text { Disease management } \\
\text { Diathene M-45 }(0.3 \%) \\
\text { Diathene Z-78 }(0.3 \%) \\
\text { Fytolan }(0.3 \%) \\
\text { Control }\end{array}$ & $\begin{array}{l}8.5 \\
7.3 \\
7.2 \\
3.4\end{array}$ & $\begin{array}{l}\text { Spraying fungicides at an } \\
\text { interval of } 15 \text { days after } 40 \\
\text { days of sowing controlled the } \\
\text { late blight disease }\end{array}$ & $\begin{array}{l}\text { i) Availability of quality } \\
\text { fungicide in the market } \\
\text { is a constraint } \\
\text { ii) Farmers are unknown } \\
\text { about the technical } \\
\text { know-how }\end{array}$ & Bhardwaj et al., 1981 \\
\hline $\begin{array}{l}\text { Lentil and } \\
\text { chickpea }\end{array}$ & $\begin{array}{l}\text { Best cultural practices } \\
\text { Lentil } \\
\text { Chickpea }\end{array}$ & $\begin{array}{l}1.8 \\
1.7\end{array}$ & $\begin{array}{l}\text { i) } 20: 40: 20 \mathrm{~kg} / \mathrm{ha} \\
\mathrm{N}: \mathrm{P}_{2} \mathrm{O}_{5}: \mathrm{K}_{2} \mathrm{O} \\
\text { ii) seed rate - } 40 \mathrm{~kg} / \mathrm{ha} \text {, } \\
\text { iii) sowing- } 12 \text { November } \\
\text { iv) } 1 \text { weeding at } 40 \text { DAS } \\
\text { v) } 2 \text { irrigations at flowering } \\
\text { and pod setting, } \\
\text { vi) } 2 \text { sprays of Decis @ } 2.5 \\
\mathrm{ml} / \text { lit of water }\end{array}$ & $\begin{array}{l}\text { i) Soil moisture deficiency } \\
\text { during the post anthesis } \\
\text { period } \\
\text { ii) Severe incidence of } \\
\text { Heliothis armigera } \\
\text { Hubner (pod borer) } \\
\text { iii) Inadequate pod filling in } \\
\text { chickpea } \\
\text { iv) Seedling stage sensitive } \\
\text { to excess moisture }\end{array}$ & Dahal et al., 2000 \\
\hline
\end{tabular}

\section{Maize-based systems}

An intercropping experiment with maize and soybean showed that the intercropped soybean yields were less for all intercropping arrangements $(1 \mathrm{~m} \times 5 \mathrm{~cm}$ and $50 \mathrm{~cm} \times 5 \mathrm{~cm}$ spacing for soybean with $1 \mathrm{~m} \times 20 \mathrm{~cm}$ and $50 \mathrm{~cm}$ x $20 \mathrm{~cm}$ spacing for maize) than the mono-cropped soybean $(50 \mathrm{~cm} \times 20 \mathrm{~cm}$ and $50 \mathrm{~cm} \times 5 \mathrm{~cm})$. Soybean yield of 0.7 to $0.9 \mathrm{t} /$ ha was harvested without reducing maize yield by intercropping maize with soybean in various planting arrangements. The arrangements tested were planting 4 rows of soybean in between 2 paired rows of maize spaced $2 \mathrm{~m}$ apart, one row of soybean between two rows of maize $1 \mathrm{~m}$ apart, and planting soybean on both sides of maize rows spaced $1 \mathrm{~m}$ apart. Gross monetary returns and LER were also higher for those planting arrangements (Neupane, 1983).

\section{Winter crop-based systems}

Three field trials, each in wheat, rape and potato, were conducted in winter season at Rampur to study their response to weed control (Shivakoti et. al, 1977). Results revealed that winter crops were infested with only a single flush of weeds. When these weeds were removed manually 45 days after sowing (DAS) in wheat and 32 DAS in rape, significant increments in their grain yields $(13.2 \%$ and $41 \%$, respectively) were obtained. Results further revealed that the most common weed species in wheat and rape was Polygonum plebejum. In potato, the predominant weed was Chenopodium album, but no special weeding efforts were necessary since the first ridging of the crop destroyed all weeds present. In another intercropping experiment with wheat and lentil, nine different 
planting arrangements were compared to identify the best intercropping arrangement (Bhattachan et al., 1993). The yield of intercropped lentil did not differ significantly from the mono-cropped lentil, while the yield of intercropped wheat differed from the mono-cropped wheat. The yield of lentil ranged from 0.61 to $0.91 \mathrm{t} / \mathrm{ha}$ while the yield of wheat from 4.58 to $11.51 \mathrm{t} / \mathrm{ha}$. Wheat when sown either at $25 \mathrm{~cm}$ spacing with lentil broadcast, or sown at $25 \mathrm{~cm}$ apart with lentil at $25 \mathrm{~cm}$ spacing gave similar and the highest yields, but wheat sown at $75 \mathrm{~cm}$ spacing with lentil broadcast gave the highest gross margin.

\section{Yield gap analysis}

Potential yield of various crops, as reported by MOAC (2002/03), shown in Table 6, are based on the average potential yields of major varieties grown in the Terai region. Similarly, the experimental yields are the IAAS station's means from various experiments and average farmers' yields are expressed on the basis of average Chitwan district yields.

Table 6. Yields and yield gaps ( $\mathrm{t} / \mathrm{ha}$ ) of major crops in Chitwan

\begin{tabular}{|lcccccc|}
\hline Crops & $\begin{array}{c}\text { Potential } \\
\text { yield (A) }\end{array}$ & $\begin{array}{c}\text { IAAS Station } \\
\text { yield (B) }\end{array}$ & $\begin{array}{c}\text { Farmers } \\
\text { yield (C) }\end{array}$ & $\begin{array}{c}\text { Yield gap 1 } \\
\text { (A-B) }\end{array}$ & $\begin{array}{c}\text { Yield gap 2 } \\
\text { (B-C) }\end{array}$ & $\begin{array}{c}\text { Yield gap 3 } \\
\text { (A-C) }\end{array}$ \\
\hline Rice & 5.50 & 3.40 & 2.74 & 2.1 & 0.66 & 2.76 \\
Maize & 4.40 & 3.30 & 1.82 & 1.1 & 1.48 & 2.58 \\
Wheat & 5.00 & 3.50 & 1.88 & 1.5 & 1.62 & 3.12 \\
Finger millet & 3.30 & 2.20 & 1.09 & 1.1 & 1.11 & 2.21 \\
Rapeseed and mustard & 1.10 & 1.00 & 0.71 & 0.1 & 0.29 & 0.39 \\
Soybean & 2.00 & 1.50 & 0.85 & 0.5 & 0.65 & 1.15 \\
Lentil & 2.50 & 1.75 & 0.82 & 0.75 & 0.93 & 1.68 \\
Potato & 20.0 & 16.5 & 10.90 & 3.5 & 5.6 & 9.1 \\
\hline
\end{tabular}

Source: Ministry of Agriculture and Co-operatives (2002/03), HMG, Nepal and various research papers of IAAS (Adapted and modified from Amgain and Timsina, 2004); (A) Potential yields for rice and maize are for Masuli and Rampur Composite, while for wheat are an average of NL-297, UP-262, and BL-1473. For other crops they are averages for available and tested varieties. (B) Experimental station yields of various varieties under test, and (C) Averge yields of various cultivars grown in farmers' field in Chitwan

The cursory view of data in Table 6 indicates that the potential yields of major crops grown in Chitwan valley are quite low. The common rice cultivar Masuli grown in Chitwan has the yield potential of $5.5 \mathrm{t} / \mathrm{ha}$, whereas maize cultivar 'Rampur Composite' has the yield potential up to $4.4 \mathrm{t} / \mathrm{ha}$ (MOAC, 2002/03) only. The popular wheat varieties in Chitwan are NL-297, UP-262, BL-1473, and these have an average of $5.0 \mathrm{t} / \mathrm{ha}$ yield potential (MOAC, 2002/03). The yields of rapeseed and mustard are quite low (potential yield $1.1 \mathrm{t} / \mathrm{ha}$ ) as most of the varieties grown are local in type, and are highly susceptible to Alternaria blight and aphids. More emphasis is needed for the identification of suitable varieties of rapeseed and mustard since they contribute to about $90 \%$ of oil/lipids requirements in Nepal. The potato cultivars, Desiree, Cardinal, Kufri Jyoti, etc. have the yield potential up to $20.0 \mathrm{t} / \mathrm{ha}$ (MOAC, 2002/03).

The yields of rice, maize and potato are increasing steadily in Nepal but the yields of wheat, rapeseed, mustard and lentil are declining over time. The gaps between the potential and farmers' field yields (yield gap 3) of major crops are: $2.76 \mathrm{t} / \mathrm{ha}$ for rice, $2.58 \mathrm{t} / \mathrm{ha}$ for maize, $3.12 \mathrm{t} / \mathrm{ha}$ for wheat and $9.1 \mathrm{t} / \mathrm{ha}$ for potato. It is low $(0.39 \mathrm{t} / \mathrm{ha})$ for rapeseed and mustard but their potential yields are also low. For rice, the yield gap between potential and research station yields (yield gap 1) is larger than that for maize and wheat, suggesting that improved agronomical research on rice varieties and crop and soil management would be required to reduce this gap. The gap between research station and farmers' field yields (yield gap 2) is larger for wheat than for the other two crops suggesting the farmers' management for wheat is poor and that extension of recommended technologies and their adoption by farmers would help increase farmers' yields and reduce the gap. The results suggest that there is great scope to raise yields of all cereals in farmers' fields, more so for wheat and maize than rice. For rape and mustard, all three forms of yield gaps are smaller, suggesting less scope for improvement through agronomic research. For soybean, lentil, and potato, however, the gap between potential and farmers' field yields is much larger than the other yield gaps, suggesting large scope for increase in yields in farmers' fields through both improved management and improved varieties. Since the potential yield is governed by both 
biotic and abiotic factors, it is often difficult to harvest the same yield either in farmers' field or in an experimental research station. The experimental station yields, identified as direct research outputs, would seem to be cost effective technologies to the farmers of Chitwan.

This review has identified the research results of various agronomical crops together with the extent of yield gaps. Other survey works and interaction with farmers of Chitwan indicate that reducing supply of organic manures, rainfed agriculture system (only about 20\% area of the district has the assured irrigation source), imbalanced use of chemical fertilizers (urea only), decreasing soil fertility, insect pests and disease attack (especially in rice, potato and rapeseed and mustard), recurrent flooding during monsoon (river basin areas of eastern Chitwan), poor accessibility of resource and technology, intensive cropping, etc. are also other possible causes of lower productivity of major crops in Chitwan.

\section{Future research priorities}

Since the commencement of APP in 1993/94, the national research issues in Nepal are focused on the agricultural problems prevalent in the farmers' fields (Joshy and Rajbhandari, 2001). Bridging the gaps between potential and experimental station yields, between experimental station and farmers' field yields, and between potential and farmers' field yields are possible only through the rigorous scientific agricultural research. While the research conducted so far at IAAS has certainly contributed to narrowing the various gaps to some extent, it seems that such research have not contributed significantly to increase the yields of various crops in the farmers' fields because research and extension systems have not sufficiently and effectively addressed the farmers' needs or reached their fields.

A range of innovative and relevant research programs, including effective and efficient on-farm research and extension systems, may be needed to substantially narrow the yield gaps and benefit the farmers. For example, in rice, biodiversity maintenance, high quality and aromatic rice production, development of high yielding varieties and eco-region suited technology identification through crop modeling and agro meteorological studies should be given emphasis. Variety identification and testing for uplands, ecological zone classification and technology identification through modeling, and hybrid seed production could be some priority areas for maize research. Search for the cost- and energy-efficient land preparation options is major challenge for wheat in the rice-wheat system. Integrated nutrient management (INM) techniques should be emphasized in cropping system research. True potato seed (TPS) production, and post harvest management studies, etc. are options to increase the potato yields. Aphid and Alternaria leaf blight disease management strategies (e.g. development of resistant varieties and management of fertilizer inputs) could be the ways for sustainable yields of oilseed crops. Both internal and external funding would be required to continue and flourish the agronomical research work at IAAS.

\section{ACKNOWLEDGEMNTS}

This study is the result of inspiration of Mr. Thaneshwor Pokharel, Senior Scientist and Agronomist, NARC, Khumaltar. The comments and suggestions provided by Dr. N.R. Devkota is highly acknowledged.

\section{REFERENCES CITED}

Adhikari, B.B., K.B. Basnet, K.R. Dahal, and D. N. Yadav. 2002. Nitrogen use efficiency in rice under different levels of nitrogen and mulching materials. J. Inst. Agric. Anim. Sci. 23: 59-64.

Adhikari, K. 1990. Response of maize to different planting densities, foliage removal practices and thinning times. J. Inst. Agric. Anim. Sci. 11: 105-112.

Adhikari, K. R. 1995. Effect of lime and texture on soil reaction and yield of wheat from Chitwan Valley, Nepal. J. Inst. Agric. Anim. Sci. $16: 71-75$.

Adhikari, K. R. 1998-99. Induced compaction and manuring effects of selected soil properties and growth of wheat under irrigation. J. Inst. Agric. Anim. Sci.. 19-20: 65-70.

Adhikari, K. R., N. K. Mishra and A. P. Shrestha. 1993. Response of wheat to added lime in acid soil. IAAS Research Reports (1985-1991). Inst. Agric. Anim. Sci. Rampur, Chitwan: 560-563. 
Adhikari, N. R. and R. C. Sharma. 2000. Variation in sterility among genotypes of bread wheat (Triticum aestivum L.) in Nepal. IAAS Research Reports (1995-2000). Inst. Agric. Anim. Sci. Rampur, Chitwan: 123-135.

Amgain, L.P. and J. Timsina. 2004. Crop and cropping system research in the central Terai, Nepal. Poster paper presented in 4ICSC, Brisbane, Australia during September 26 to October 1, 2004.

Amgain, L.P. and K.R. Dahal. 2002. Effect of different nursery management practices and rice varieties on the yield and yield attributes of rice under single seedling transplanting conditions at Rampur, Chitwan. Paper presented to the National Conference of SRI on 15th April, 2002 in Kathmandu, Nepal.

APP.1995. Agricultural Perspective Plans of Nepal, His Majesty's Government of Nepal.

Basnet, K. B., B. P. Rajbhandari and N. K. Mishra. 1993. Improved technology generation for finger millet yield improvement under rainfed condition at Rampur, Chitwan. IAAS Research Reports (1985-1991). Inst. Agric. Anim. Sci. Rampur, Chitwan, Nepal: 329-340.

Basnet, K. B., M. D. Sharma and R. C. Adhikari. 1998-99. Response of potato to mineral fertilization under the humid sub-tropical condition of Chitwan. J. Inst. Agric. Anim. Sci. 19-20: 91-96.

Bhardwaj, L. N., N. K. Mishra and D. N. Sah. 1981. Efficacy of different fungicides for the control of leaf blight of potato at Rampur, Chitwan, Nepal. J. Inst. Agric. Anim. Sci. 2 :1-6.

Bhattachan, B. K., R. C. Sharma and N. K. Mishra. 1993. Performance of wheat and lentil as monocrop and intercrop with different spacing in rainfed condition. IAAS Research Reports (1985-1991). Inst. Agric. Anim. Sci. Rampur, Chitwan, Nepal: 462-466.

Chaudhary, N. K. 1995. Orobanche damage in winter crops. J. Inst. Agric. Anim. Sci. 16: 61-66.

Chaudhary, N. K., N. K. Mishra and R. C. Sharma. 1993. Study of weed control through soil and foliage applied herbicides and cultural methods in paddy on loamy soil of Rampur. IAAS Research Reports (1985-1991). Inst. Agric. Anim. Sci., Rampur, Chitwan: 166-168.

Chaudhary, N. K., N.K. Mishra and S.C. Sah. 1988. Effectiveness of Nitrogen application in rainfed wheat at different weed control methods. J. Inst. Agric. Anim. Sci. 9: 29-33.

Chaudhary, N. K., R. C. Sharma and N. K. Mishra. 1993a. Effects of plant population on stand establishment in wheat. IAAS Research Reports (1985-1991). Inst. Agric. Anim. Sci., Rampur, Chitwan: 232-235.

Chaudhary, N. K., R. C. Sharma and N. K. Mishra. 1994. Yield performance of wheat cultivars at different seeding dates in relation to rate of grain filling and grain filling period. IAAS Research Reports (1992/93). Inst. Agric. Anim. Sci., Rampur, Chitwan: 1-9.

Chaudhary, N. K., R. C. Sharma, N. K. Mishra and K. R. Dahal. 1993b. Weed and fertilizer management in rapeseed and mustard. IAAS Research Reports (1985-1991). Inst. Agric. Anim. Sci., Rampur, Chitwan: 527-531.

Chaudhary, N.K., U.S. Gupta, S. C. Sah and M. Prasad. 1985. Response of wheat to zinc fertilization at different levels of posphorus under rainfed condition of Rampur, Chitwan. J. Inst. Agric. Anim. Sci. 6: 105-112.

Dahal, K. R., G. R. Bhattarai and C. Shrivastav. 2000. Study on the constraints to winter legume production at Rampur and its vicinity in Chitwan: A system approach. IAAS Research Reports (1995-2000): 137-142.

Dahal, K. R., N. K. Mishra, and K. P. Sharma. 1993. Feasibility study of sunflower (Helianthus annuus L.) cultivation in Rampur Chitwan. IAAS Research Reports (1985-1991). Inst. Agric. Anim. Sci., Rampur, Chitwan: 317-322.

Dahal, K. R., N. K. Mishra, B. P. Rajbhandary, N. K. Chaudhary and M. L. Prasad. 1993. Green manuring studies on rice. IAAS Research Reports (1985-1991). Inst. Agric. Anim. Sci., Rampur, Chitwan: 40-43.

Dahal, K. R., S. B. Gurung, J. Timsina and N. K. Mishra. 1995. Relationship between morpho-physiological traits and yield of some rice cultivars. IAAS Research Reports (1993/94). Inst. Agric. Anim. Sci., Rampur, Chitwan: 15-21.

Dangol, D. R. 1998-99. An inventory of plant bio-diversity of Rampur, Chitwan, Nepal. . J. Inst. Agric. Anim. Sci. 19-20: 27-40.

Dangol, D. R. and I. D. Bhattarai. 1993. Study on the weeds of Terai rice fields in Nepal. IAAS Research Reports (1985-1991). Inst. Agric. Anim. Sci., Rampur, Chitwan: 310-316.

Dangol, D. R. and N. K. Chaudhary. 1994. Wheat-weed interactions at Rampur, Chitwan. IAAS Research Reports (1992/93). Inst. Agric. Anim. Sci., Rampur, Chitwan: 19-37. 
Dangol, D. R. and S. B. Gurung. 1989. Floristic composition and dominance of weeds in maize fields in Chitwan valley of Nepal. J. Inst. Agric. Anim. Sci. 10: 57-66.

Dangol, D. R., S. B. Gurung, I. D. Bhattarai and N. K. Chaudhary. 1993. Survey of weeds of major crops at Rampur and vicinity in Chitwan, Nepal.. IAAS Research Reports (1985-1991), Inst. Agric. Anim. Sci., Rampur, Chitwan: 9-17.

Dangol, D. R.; S.B. Gurung, and I Bhattarai. 1986. Lowland rice weeds at the Agronomy Farm of IAAS Rampur, Chitwan,Nepal. J. Ist. Agric. Anim. Sci. 7:1-12.

Gupta, O. P., G.R. Chaudhary, R.G. Bansal and G. D. Didwania. 1977. Evaluation of response of potato (Solanum tuberosum L.) to chemical control of early weed infestation. J. Inst. Agric. Anim. Sci. 1 (1): 97-101.

Gupta, O. P., S. R. Bajraracharya and G.P. Shivakoti. 1977. A study of weed problem at Rampur, Chitwan, Nepal. J. Inst. Agric. Anim. Sci. 1(1): 1-86.

Gupta, U.S. 1985. Performance of some cultivars of soybean (Glycine max L. Merr.). J. Inst. Agric. Anim. Sci. 6: 89-98.

Gurung, S. B., O. P. Gupta and N. Kunwar. 1977. Response of unirrigated potato ( Solanum tuberosum L.) to NPK application at Rampur, Chitwan, Nepal. J. Inst. Agric. Anim. Sci. 1 (1): 111-118

IAAS Bulletin. 2003. Tribhuvan University, Institute of Agriculture and Animal Science, Rampur Campus, Rampur, Chitwan, Nepal. PP: 1-7.

Joshy, D. and N. P. Rajbahandari. 2001. Agricultural development and food security in Nepal: Constraints and potential. In: H.K. Manandhar, C.L. Shrestha, R.K. Shrestha and S.M. Pradhan (eds.) Advances in Agricultural Research in Nepal. Society of Agricultural Scientists (SAS) Nepal: pp. 24-29.

Karki, P. B. 1991. Rice response to bacterial leaf blight. J. Inst. Agric. Anim. Sci. 12: 115-119.

Khadka, S. R. and S. C. Sah. 1993. Different tillage practices and their effects on the yield of spring maize (Zec. mays L.). IAAS Research Reports (1985-1991). Inst. Agric. Anim. Sci. Rampur, Chitwan: 18-23.

Khairgoli, L.P. 1982. Effect of whole and half seed tubers on the yield potato cultivar Kufri Jyoti. J. Inst. Agric. Anim. Sci. 3 (1):13-18.

Khakural, B. R., J. T. Joshi and H. D. Foth. 1984. Mapping and characterizatrion of IAAS Farm soils. IAAS Research Report (1982-84) pp 61-79. IAAS Rampur, Chitwan, Nepal.

Khatri Chhetri, T. B. and E. E. Schulte. 1985a. Response of maize to the application of secondary and micronutrients in the soils of the Chitwan Valley, Nepal. I- Results of IAAS and NMDP Farm. Nepalese J. Agricultute 16: 48-56.

Khatri Chhetri, T. B. and E. E. Schulte. 1985b. Response of maize to the application of secondary and micronutrients in the soils of the Chitwan Valley, Nepal. II- Results of Multi Location Trials. J. Inst. Agric. Anim. Sci. 6: 59-76

Koirala, K. P. and B. Alipit. 1986. Effects of pre-sowing wetting and drying on the vigor and germination of the maize seeds. J. Inst. Agric. Anim. Sci. 7:119-122.

Mishra, N. K, R. C. Sharma, R. B. Thapa, S. M. Shrestha and N. K. Chaudhary. 1994. Response of rapeseed and mustard group of oilseed crops (var Brassica spp.) to different seedling dates grown under rainfed condition at Rampur Chitwan. IAAS Research Reports (1992/93). Inst. Agric. Anim. Sci., Rampur, Chitwan: 49-57.

Mishra, N. K, R. C. Sharma, R. B. Thapa, S. M. Shrestha and N. K. Chaudhary. 1995. Response of rapeseed and mustard group of oilseed crops (Var Brassica spp.) to different seedling dates grown under rainfed condition at Rampur Chitwan. IAAS Research Reports (1993/94). Inst. Agric. Anim. Sci., Rampur, Chitwan: 51-55.

MOAC 2002/03. Ministry of Agriculture and Co-operatives, HMG/N, Singhadarbar, Kathamandu Nepal. (In) Agriculture Diary of Nepal. PP: 3-37.

Nepal T. P. 1980. Comparative performance of five wheat genotypes in Rampur Chitwan. J. Inst. Agric. Anim. Sci. 3 (1): 7-11.

Neupane, F. P., R.K. Champman and H.C. Coppel. 1983. Effect of date of planting on maize on the incidence of the maize borer (Chilo partellus (Swinehoe) in Nepal. J. Inst. Agric. Anim. Sci. 4 (1 \& 2):77-79.

Neupane, R.K. 1983. Effect of planting arrangements on maize and soybean intercropping. J. Inst. Agric. Anim. Sci. 4 (1\& 2): 1-6.

Pandey, K. C. 1977. Effect of time of planting and insecticide application on mustard aphid (Lipaphis erysimi Kalt. ) in rape. J. Inst. Agric. Anim. Sci. 1 (1): 87-91. 
Pandey, S. P. 1983. Greeen manuring paddy with Sesbania aculeata (Dhaincha) at various levels of fertilizers Nitrogen. J. Inst. Agric. Anim. Sci. 4 (1 \& 2):35-40.

Pandit, K. N., A. K. Shukla and N. K. Mishra, 1993. Effects of tillage on soil physical environment, yield and yield attributing parameters of wheat. IAAS Research Reports (1985-1991). Inst. Agric. Anim. Sci., Rampur, Chitwan: 110-113.

Panthee, D. R. 1996-97a. Efficacy of six different indigenous pesticides for wheat seed storage. J. Inst. Agric. Anim. Sci. 17-18: 71-76.

Panthee, D. R. 1996-97b. Identification of a suitable indigenous storage structure for wheat seed storage. J. Inst. Agric. Anim. Sci. 17-18: 55-63.

Rajbhandari, B. P., N. K. Mishra and K. B. Basnet. 1993. Exploitation of biological yield potential of groundnut genotypes under humid sub-tropical climate at Rampur, Chitwan. IAAS Research Reports (1985-1991). Inst. Agric. Anim. Sci. Rampur, Chitwan: 346-353.

Rajbhandari, B. P. and N. K. Mishra. 1993. Buckwheat research at IAAS. Phase I. IAAS Research Reports (1985-1991). Inst. Agric. Anim. Sci. Rampur, Chitwan : 221-231.

Rajbhandari, B.P. 1991. Growth and development of buckwheat ecotypes in the humid sub- tropical climate. J. Inst. Agric. Anim. Sci. 12: 79- 83.

Rajbhandari, B.P. and N.K. Mishra. 1987. Performance of introduced groundnut genotypes under rainfed conditions at Rampur, Chitwan. J. Inst. Agric. Anim. Sci. 8:1-10.

Sah, S. K. and N. K. Mishra. 1995. Effect of seeding rates and crop geometry on yield and yield components of rapeseed. IAAS Research Reports (1993-94). Inst. Agric. Anim. Sci. Rampur, Chitwan: 43-46.

Sah, S.C., T. B. Khatri-Chhetri and N.K. Chaudhary. 1989. Response of summer mungbean to phosphorus fertilization at different levels of sulphur under rainfed conditions of Chitwan. J. Inst. Agric. Anim. Sci. 10: 75-80.

Sah, S.C., T.B. Khatri Chhetri, D.N.Yadav and M. Prasad. 1985. Effect of nitrogen and sulphur fertilizers on grain yield and oil content of mustard crop (Brassica campestris L.). J. Inst. Agric. Anim. Sci. 6: 77-88.

Sharma, K. P. 1983. Influence of genotype and environment on field performance of soybeans (Glycine max (L.) Merrill.). J. Inst. Agric. Anim. Sci. 4 (1 \& 2):65-71.

Sharma, K. P. 1987. Response of soybean cultivars to different levels of Rhizoctina solani inoculum. J. Inst. Agric. Anim. Sci. 8:89-98.

Sharma, K. P. 1994. Soybean production in Nepal: Past achievements and future prospects. J. Inst. Agric. Anim. Sci. 15:19-26.

Sharma, K.P. 1985. Implication of planting dates on seed yield determination of four determinate soybean cultivars. Nepalese J. Agriculture 16: 1-6.

Sharma, K.P., K.R. Dahal and B. Subedi. 1991. Genotype x Canopy selection interaction for flower production, abortion and seed yield in soybean. J. Inst. Agric. Anim. Sci. 12: 79-83.

Sharma, K.P., K.R. Dahal. and B. P. Subedi. 1990. Raceme length and thickness in relation to flower production and abortion in soybean. J. Inst. Agric. Anim. Sci. 11: 1-8.

Sharma, P. P., R. R. Khakural, B. Chhetri and T. B. Khatri Chhetri. 1984. Contribution of dew in winter wheat in Rampur, Chitwan. J. Inst. Agric. Anim. Sci. 5:71-82.

Sharma, P. P., J.R. Joshi, H.K. Upadhyaya and S. P. Shrivastava. 1985. Conservation tillage research on summer crop maize- I Rampur, Chitwan, Nepal. Maize and Fingermillet (in) The 12th Summer crops Workshop, NMRP, Rampur, Chitwan, Nepal: 55-65.

Sharma, R. C. 1987. Yield and yield components responses of wheat cultivars to seeding rate. J. Inst. Agric. Anim. Sci. 8:99-110.

Sharma, R. C. 1993a. Study of selected morphological traits of wheat. IAAS Research Reports (1985-1991). Inst. Agric. Anim. Sci. Rampur, Chitwan: 584-590.

Sharma, R. C. and N.K. Chaudhary. 1988. Variations for vegetative growth traits in wheat genotypes adapted in Nepal. J. Inst. Agric. Anim. Sci. 9: 1-6.

Sharma, R. C., N. K. Chaudhary and S. M. Shrestha. 1994. Performance of regional wheat differing in resistance to leaf blight. J. Inst. Agric. Anim. Sci. 15:67-71. 
Sharma, R.C. 1990. Performance of wheat genotypes differing in coleoptile length. J. Inst. Agric. Anim. Sci. 11: 41-46.

Sharma, R.C. 1991. Inheritance of root length in wheat. . J. Inst. Agric. Anim. Sci. 12: 105-108.

Sharma, R.C. 1992. Genetic control of grain filling duration in wheat. J. Inst. Agric. Anim. Sci. 13: 79-82.

Sharma, R.C. 1993b. Growth periods in relation to seeding time and performance of spring wheat. J. Inst. Agric. Anim. Sci. 14: 23-30.

Sharma, R.C., N. K. Chaudhary and N. K. Mishra. 1993c. Determination of grain yield influencing traits in spring wheat. IAAS Research Reports (1985-1991). Inst. Agric. Anim. Sci. Rampur, Chitwan: 114-119.

Shivakoti, G.P, O. P. Gupta and S.R. Bajracharya. 1977. Response of wheat, rape and potato to weeding at Rampur Chitwan, Nepal. J. Inst. Agric. Anim. Sci. 1 (1): 103-109

Shrestha, G.K. and D.D. Dhakal. 1981. Effects of planting methods, numbers of sprouts and earthing up on unirrigated potato. J. Inst. Agric. Anim. Sci. 2 (2): 7-12

Shrestha, S. M. and N. K. Mishra. 1994. Evaluation of common cultivars of rice against leaf and neck blast in Nepal. J. Inst. Agric. Anim. Sci. 15:101-103.

Shrestha, S.M. and L.N. Bhardwaj. 1985. Effect of seeding dates and nitrogen levels on the incidence of host on Masuli variety of rice at the nursery stage. Nepalese J. Agriculture 16: 124 -128.

Thapa, R.B. and J. Timsina. 1992. Incidence of bean fly Ophiemiya phaseoli (Tryon) in mungbean and soybean varieties after late rice. J. Inst. Agric. Anim. Sci. 11:83-88.

Timsina, J. 1988. Performance of IITA's grain and vegetable type cowpea in Chitwan Nepal. J. Inst. Agric. Anim. Sci. 9: 21-27.

Timsina, J. 2001. Working with farmer groups- experiences, benefits and problems. Journal for Farming Systems Research- Extension. Special International Symposium Edition. pp. 29-56

Timsina, J. and R.B. Thapa. 1991. Effect of defoliation on grain yield of cowpea. J. Inst. Agric. Anim. Sci. 12: 109-113.

Yadav, D. N., S.C. Sah and M. Prasad. 1985. Agronomic studies on green gram (Vigna radiata L. Wilczek) sown at different dates and row spacings. J. Inst. Agric. Anim. Sci. 6: 99-104.

Yadav, R. N. and A. P. Shrestha. 1993. Effect of different doses of Phosphorus and Potassium on grain yield of mungbean (Vigna radiata) under upland condition of Rampur, Chitwan, Nepal. IAAS Research Reports (1985-1991). Inst. Agric. Anim. Sci., Rampur, Chitwan: 341-345.

Yadav, R. N., T. B. Khatri-Chhetri and N. K. Mishra. 1994. Response of wheat (Triticum aestivum L.) to the application of secondary and micronutrients under Rampur condition. IAAS Research Reports (1992/ 93). Inst. Agric. Anim. Sci. Rampur, Chitwan: 38-42. 